\title{
Introduction to the Edition
}

\subsection{General Remarks on the Transmission of the Abhinavabhäratī}

The text of the Abhinavabhäratī is available today in a number of manuscripts and printed editions. Besides being the only commentary on the Nātyaśāstra to have come down to us, this exegetical work represents a sort of repository of previous glosses, commentaries, and fragments of related works. The Abhinavabhäratī in fact incorporates, through quotations and cursory references, a number of different texts and living traditions that developed between the time of Bharata and that of Abhinavagupta. But what happened afterwards? What is the legacy left by the Abhinavabhäratī? How was the text preserved and transmitted and how did the present text come about?

All the available manuscripts of the Abhinavabhārati postdate the original work by many centuries and contain many passages that look corrupt beyond any possible reconstruction. As Sheldon Pollock remarks, part of the responsibility for this state of affairs may be assigned to Abhinavagupta himself: 'his thinking is subtle, sometimes even counterintuitive, and he expresses his thoughts in a style virtually unique among Sanskrit authors for its Hegelian syntactical complexity and Heideggerian semantic idiosyncrasy. Frequently his style is refreshing; sometimes it is turbid as well as turgid; occasionally it is maddening. Added to this (and possibly as a result of it), his major work on aesthetics suffered terribly in the course of transmission' (Pollock 2016: 193).

Despite their poor condition, a careful inspection and collation of the available manuscripts and editions for the section edited here allow us to formulate a number of hypotheses on the transmission of the fourth chapter of Abhinavagupta's commentary up to the present day. Moreover, the genealogy of the present text may be tentatively reconstructed by cross-examining the indirect transmission, witnessed by the external testimonies. This should avert the risk of overextending general considerations that may hold true for some of the sections of the Abhinavabhärati to the totality of the text. ${ }^{1}$ In his recent

1 In most likelihood, such an extensive text did not circulate principally in complete copies, as the lacuna spanning chapters 7 and 8 in all manuscripts suggests. This means that quite a different set of manuscript relations might exist for the different sections of the work transmitted independently of one another. 
study of the commentary on the rasa-sütra and other related passages from the first and sixth chapters, Pollock (2016:189) concludes that the Abhinavabhära$t \bar{\imath}$ must have fallen into desuetude soon after it left Kashmir, and that in any case, nobody read it after the twelfth century, even beyond Kashmir. He argued that Abhinavagupta's aesthetic theory was transmitted mainly through Abhinavagupta's commentary on the Dhvanyāloka and through Mammața's synthesis of the latter in his Kāryaprakāśa ('Light on Poetry'), composed around 1050. He further states that the text of the Abhinavabhäratī was preserved in a single manuscript and a few late medieval copies of it, all stemming from Malabar.

The present editorial work shows that the first point cannot be generalized to the whole of the Abhinavabhäratī. In my study of the fourth chapter, I have come across three independent works, belonging to different regions and periods, that reuse parts of Abhinava's commentary sometimes almost verbatim and without acknowledging their source, others by rewriting the prose into verse. The first textual reuse ${ }^{2}$ of the fourth chapter of the Abhinavabhärati can be detected in the two auto-commentaries on Hemacandra's Käryānuśāsana ('Instruction on Poetry'), the Alamkāracū sub-commentary Viveka (KAV). Both commentaries were composed by the Jain author Hemacandra, who was active in Gujarat in the middle of the twelfth century. ${ }^{3}$ The last chapter of the Kāryānuśāsana, the eighth, is devoted to the description of literary genres. An original distinction is introduced here between what Hemacandra dubs 'poetry to be recited' (pāthya-kārya) and 'poetry to be sung' (geya-kārya). ${ }^{4}$ In the Viveka on this passage (pp. 445-449), Hemacandra incorporates long textual portions of Abhinavagupta's debate about the nature of dance and its difference from theatre, found in the fourth chapter of the Abhinavabhäratī. In Hemacandra's work, however, the discussion centres exclusively on poetic genres, so the Jain author leaves out the specific context in which the debate originated, namely the determination of

2 On textual reuse, see Freschi 2015 and 2017.

3 On Hemacandra's work and poetics, see, e.g., Upadhyay 1987; Kulkarni 2003: 91-96; and Tubb 1998. For a German translation of the first two chapters of the Käryānuśāsana with the Vrtti (Alamkāracūdāmanii) and Viveka, see Both 2003. The relationship between Hemacandra and Abhinavagupta with respect to aesthetic theory has been treated cursorily in Pollock 2016. On Hemacandra's reuse of the Abhinavabhāratī, see Cuneo 2017.

4 On the distinction between theatrical and dance genres as underlined by these categories, see $\S$ 2.1. Hemacandra's distinction stems from the super-category of 'poetry to be seen' (prekssya$k \bar{a} v y a$ ), itself distinguished from 'poetry to be heard' (śravya-kārya). On the latter classification in treatises on dramatics and poetics, see Pollock 2012a. 
the nature and function of dance within (and without) the enactment of a play. His original textual source is moreover left unacknowledged. ${ }^{5}$

The second text to draw on the Abhinavabhäratì's fourth chapter is the Samgìtaratnākara ('Ocean of Music and Dance') (sR), ${ }^{6}$ written presumably before 1247 by Śāngadeva, who was active in the northern Deccan under the Yādava king Singhana of Devagiri. His work, as its title indicates, deals with sam gitta, an inclusive term that in the technical literature comes to designate the 'concert' or 'recital', intended as a combination of vocal music ( gitta), instrumental music ( $v \bar{a} d y a)$, and dance ( $n r t t a)$. Its seventh chapter, devoted to dance, is practically a versification of the Abhinavabhäratī, though not one particularly concerned with its aesthetic and poetic aspects. The section translated and analysed in this book does not find any parallel in it, most probably due to the fact that the Samgitaratnākara is not a text concerned with theatrical practice and has omitted all references to it. The name of Abhinavagupta is mentioned among other commentators on the discipline of Nātyaśāstra in SR 1.19, and in chapter seven, Sārngadeva quotes him twice by name. Incidentally, Kallinātha, who commented on the Samgittaratnākara in the second half of the fifteenth century in the southern kingdom of Vijayanāgara, appears to use the Abhinavabhāratī independently of its source text in his commentary, the Kalänidhi.7

The third text comes from the Āndhra region, and was composed in 12531254 by Jāyasenāpati. The Nrttaratnāvalī ('Necklace of Dance') (NR), ${ }^{8}$ as the work is named, is the only available medieval treatise devoted exclusively to dance. ${ }^{9}$ Similarly to the Samgittaratnākara, the Nrttaratnāvali makes extensive use of Bharata's text as interpreted by Abhinavagupta, who is however mentioned by name only once with regard to the interpretation of the hasta nișa $d a$

5 While Hemacandra's incorporation of the Abhinavabhäratī definitions of the genres of narrative dance in the Alaṃkäracū ūamaṇi has been acknowledged by Raghavan (1978), the reuse of passages from Abhinavagupta's discussion on the nature of theatre and dance has rarely been noticed. Two remarkable exceptions are Mankad (1936: 23-24) and Bhayani (1993: 20). The comparison of the relevant passages with the text of the Abhinavabhärati and its inclusion in the critical apparatus presented here is an original contribution of the present edition.

6 The Samgittaratnākara of Sārngadeva and its two commentaries, the Kalānidhi and the Sudhākara, have been edited by S. Subrahmanya Sastri. A translation of the seventh chapter of the SR, on dance, has been published by Kunjunni Raja and Burnier (1976).

7 Cf. Raghavan 1980: 103. For concrete evidence of the independent use of the Abhinavabhärati by Kallinātha, see Translation, n. 178 .

8 The Nrttaratatnāvalī is edited by Raghavan and contains a very good introduction with the parallels between this text and the Abhinavabhäratī. An English translation of the work has recently been published by Venugopala Rao (2013).

9 The Nrtyādhyāya (14th-15th c.) and the Nrtyaratnakośa (15th c.) were parts of larger works, though published independently. On these two works, see Bose 2007: 75-82. 
(NR 2.182). ${ }^{10}$ Jāyasenāpati's reliance on the fourth chapter of the Abhinavabhāratī for his description of the karanas and angahäras has been noticed and illustrated by Raghavan in his introduction to the edition. The relationship between the Nrttaratnāvalī and the Samgìtaratnākara is itself problematic, since the two works were composed around the same time in contiguous parts of the subcontinent. Historical research has shown that the neighbouring kingdom ruled at that time by king Ganapati Deva of the Kakațiya dynasty - to which Jāyasenāpati belonged — conquered the region where Śanngadeva was active. The hypothesis has been thus advanced that Jāyasenāpati knew but did not acknowledge the work of Saanrngadeva, emulating it for reasons of cultural prestige rather than practical artistic needs. ${ }^{11}$

The fact that the Abhinavabhäratī was read and studied by these three authors - or four if we take into account the independent testimony of Kallinātha-suggests an extensive circulation of manuscript sources in medieval India, and a general movement of the Abhinavabhärati towards the South. ${ }^{12}$ As a matter of fact, a manuscript tradition of the Abhinavabhäratī is extant exclusively in South India, in particular in the area of present-day Kerala. The oldest available manuscripts, written on palm leaf, belong to this area. Devanāgarī paper transcripts are found in several manuscript libraries in North India as well, although on close inspection, they all appear to be copies produced from Malayālam palm-leaf prototypes. Although this would require a separate study, it would be meaningful to assess how a systematic analysis of the borrowings from the Kāryānuśäsana, Saṃgitaratnākara, and Nrttaratnāvalī might in fact suggest new ways of looking at the textual transmission of the Abhinavabhāra$t \bar{\imath}^{13}$

10 Curiously, the section on dance in the Mānasollāsa (ca. 1130), called Nrtyavinoda, quotes the same interpretation in the definition of nișāda hasta, with a silent acknowledgement of Abhinavagupta. According to U. Srinivasan (1985: 68), this may be taken as positive evidence of the Cālukya king Someśvara's indebtedness to Abhinavagupta. According to Raghavan (NR Introduction, p. 68), the Mānasollāsa is the source of material on deśi for both the Samgittaratnākara and the Nrttaratnāvalī.

11 See Raghavan, NR Introduction, pp. 73-74.

12 Cox 2013 gives evidence for the reception of the Abhinavabhärati (at least the section on śantarasa) in Tamil Nadu as early as the late eleventh or twelfth centuries, as evidenced in the Céyirriyam, a text devoted to drama, quoted in the earliest commentary on the Tǒlkāppiyam by Illampūranar.

13 For instance, it would be interesting to determine whether the Samgitaratnākara and the Nrttaratnāvalī, which each dedicate a long section to the ängīkäbhinaya, had access to Abhinavagupta's now lost commentary on the eighth chapter at all. While they both incorporate a great deal of material from the fourth chapter of the Abhinavabhāratī on the 


\subsection{Genealogy of the Present Text: The Sources}

\subsubsection{Editions}

First of all, a few remarks on the available editions of the Nātyaśāstra and the Abhinavabhäratī are in order. Differently from $\S 1.1$, where the main aim was to present the cultural context that prompted the production of printed editions of the müla text and its commentary, in what follows I provide information on the constitution of the edited texts, including the editorial policies, textual interventions, and flaws of previous editors. In the particular case of the editio princeps and its two main revisions, I supply data about our present knowledge of specific manuscript sources that were available to and/or used by the editors in constituting the text, with particular attention to Abhinavabhäratī chapter 4.

\subsubsection{The Baroda or Gaekwad Edition $\left(=\mathrm{E}_{1}\right)$}

The project of editing the whole of the Nātyaśāstra and Abhinavabhāratī was carried out in various stages by Manavalli Ramakrishna Kavi between 1926 and 1964, but produced a number of revised editions both during and after this time.

The various volumes of this edition were published as follows:

- Vol. 1 (chapters 1-7), Gos no. 36.

- 1st edition, M. Ramakrishna Kavi (ed.), 1926. (= $\left.\mathrm{E}_{1(1)}\right)$

- 2nd edition, K.S. Ramaswami Sastri (ed.), 1956. (= $\left.\mathrm{E}_{1(2)}\right)$

- 3rd edition (abridged reprint of the 2nd edition), 1980. $\left(=\left[\mathrm{E}_{1(3)}\right]\right)^{14}$

- 4th edition, K. Krishnamoorthy (ed.), 1992. (= $\left.\mathrm{E}_{1(4)}\right)$

- Vol. 2 (chapters 8-18), gos no. 68.

- 1st edition, M. Ramakrishna Kavi (ed.), 1934. (= $\left.\mathrm{E}_{1(1)}\right)$

- 2nd edition, V.M. Kulkarni and Tapasvi Nandi (eds.), 2001. $\left(=\mathrm{E}_{1(4)}\right)^{15}$

- Vol. 3 (chapters 19-27), Gos no. 124.

- 1st edition, M. Ramakrishna Kavi (ed.), 1954. (= $\left.\mathrm{E}_{1(1)}\right)$

- 2nd edition, V.M. Kulkarni and Tapasvi Nandi (eds.), 2003. (= $\left.\mathrm{E}_{1(4)}\right)$

subject of karanas and angahäras, at first sight they do not appear to bear traces of original material that might stem from what is now a lacuna in all manuscripts.

14 This edition contains the first seven chapters of the Nätyaśästra, but only the sixth chapter of the Abhinavabhāratī. It is based on the second edition and does not incorporate any new manuscript material.

15 For the sake of convenience, although volumes 2 through 4 have only two editions each, I have named the second editions $\mathrm{E}_{1(4)}$, since these formed part of the Oriental Institute in Baroda's unified project to re-edit the whole text which, for vol. 1 alone, coincided with the fourth edition of the text. 
- Vol. 4 (chapters 28-37), Gos no. 145 .

- 1st edition, M. Ramakrishna Kavi and J.S. Pade (eds.), 1964. $\left(=\mathrm{E}_{1(1)}\right)$

- 2nd edition, V.M. Kulkarni and Tapasvi Nandi (eds.), 2006. $\left(=\mathrm{E}_{1(4)}\right)$

In his preface to the editio princeps of the first volume of the Abhinavabhārati, M.R. Kavi states that he collected forty manuscripts for editing the text of the Nātyaśāstra but does not describe any of them, nor does he explain how he used them in the collation. The text of the müla he gives is mostly in agreement with Abhinavagupta's commentary; however, at times, he brackets off some verses that he considers redundant or interpolated without indicating which manuscripts contained which verses. ${ }^{16}$ On the whole, it does not seem that Kavi had anything in front of him like a single manuscript containing what he considered the transmitted text used by Abhinavagupta, or a Kashmirian recension of the Nātyaśāstra. To be sure, from the commentary it emerges that Abhinavagupta himself consulted different witnesses of the $m \bar{u} l a$ text, since he sometimes records and discusses variant readings ( $p \bar{a} t$ thantara), cases of verses that were not read unanimously, and different readings accepted by other commentators before him. ${ }^{17}$ Since Kavi's interest was in reconstructing a text that would match Abhinavagupta's commentary as closely as possible, his edition of the Nätyaśāstra looks more like a patchwork in which the connecting threads have been effaced except for a few variae lectiones given in the apparatus, with the different sigla corresponding to the manuscripts described succinctly in the preface.

As for the text of the Abhinavabhäratī, whose edition represented the main motivation for Kavi's ambitious enterprise, the introduction informs us that two sets of manuscripts were used, as well as a summary of the commentary covering the first six chapters and probably composed by the Keralite dramatist and literary commentator Pürṇasarasvatī. According to Kavi, the first set, called A, followed the Käryānuśäsana. This set is said to be more complete, but in the fourth chapter, the palm leaves of the original manuscript were shuffled. The B set is said to be less correct, and has a lacuna in the fourth chapter shared by Pūrnasarasvatì's summary. The lacuna is said to correspond to the textual part at which set $\mathrm{A}$ has its folios mixed up.

16 This lack of transparency in the editing procedures was harshly criticized by De in his review, which came out in 1927, one year after the publication of the first volume. On De's critique of Kavi's philological process, see Ollett (forthcoming).

17 See for instance, ABh ad Nś 4.55cd-59ab, vol. 1, p. 94: atra 'aștottaraśatam' ityādi ślokam kecin na pațhanti. anye tato 'py adhikam —-'hastapādapracāran tu kațipārśvorusamyutam' iti ślokam pațanti. For an example of different readings (of Nś quotations) accepted by other commentators, see ABh ad Nś 5.21ab, vol. 1, p. 212: śankukas tu paṭhati 'uttaras tathā caiva' iti sthāne 'uttaras tathā dvikalah' iti, 'ekakala' ity atra ca sthāne 'nirdișta' iti. 
In 1929, in a much-resentful response to De's acrimonious review of the first volume of the Baroda edition, Kavi set out to describe some of the sources he used to edit the text of the Abhinavabhāratī. ${ }^{18}$ As he explains, he started to collect copies of the Abhinavabhäratī in Malabar after having determined to edit the text as early as 1912. The manuscript copies he managed to locate and secure are listed as follows:

1. MS at the Mahārāja's Library at Trivandrum, with the first 19 chapters, but full of lacunae. A copy of the MS was given by T. Ganapati Sastri to Ganganath Jha. The same copy was loaned to Kavi by the late Pandit Govinda Das of Benares.

2. MS with chapters 1 to 6: damaged but without many omissions

3. MS with chapters 9 to 31: damaged but without many omissions

4. MS in Travancore secured by Gopinath Rao, with chapters 1 to 19, as bad as the Palace copy (1.)

Manuscripts obtained by the Madras Government search party after 1915:

5. MS with chapters 1 to 19 , fairly good and complete $(=2478)^{*}$

6. $\quad$ MS with chapters 20 to $28(=2785)^{*}$

7. $\quad$ MS with chapters 30 to $32(=2774)^{* 19}$

8. Ms with chapter 6

9. $\quad$ MS with chapters 19 to 20

10. Summary of the first six chapters by Pūrṇasarasvatī

Mss obtained by Kavi on his own in Malabar:

11. MS with chapters 29 to 37

12. MS with chapters 4 to 6

Kavi further mentions that the Madras Govt. transcript (5. $)^{20}$ was collated with the copy of Ganganath Jha (the one taken on loan from Govinda Das of Benares, 1.), and claims to have consulted eight different manuscripts for

18 Kavi promised to provide a fuller description of all the sources and the variant readings in an extensive introduction that was to be published after the edition of the full text had been prepared. This project, however, was never completed, since Kavi passed away in 1957, before the publication of the fourth volume, which was taken up by J.S. Pade and completed in 1964 on the basis of a transcript of the Abhinavabhäratī, with corrections prepared by Kavi and subsequently revised by Pade at the demand of the press and the general editor (see Preface to the fourth volume by Pade).

19 As the second editor informs us (Ramaswami Sastri 1956: 26), the three manuscripts listed by Kavi (5., 6., and 7.), i.e. MSS 2478,2785 , and 2774 , were acquired by the search for manuscripts prompted by the Madras Government, and they form the basis of the transcript at the GOML, our $\mathrm{M}_{1}$, on which see more below. Although Ramaswami Sastri says that the third manuscript contains chapters 29 to 31 , direct inspection shows that it actually contains chapters 29 to 32 (incomplete).

About this transcript $\left(=\mathrm{M}_{1}\right)$, Kavi (1929:569) informs us that it was prepared by copyists at 
the sixth chapter, including the original Malayālam palm leaves whenever the transcripts were unintelligible. An interesting detail Kavi provides us with is that he also consulted (8.) 'a copy of the 6th chapter alone copied and collated by Deśamangalavariar, who was the owner of all the copies of Abhinava's works brought to the Madras Library' (1929: 56o-561). This statement needs to be contextualized. The Deśamangala Vāriyam 'is an ancient family of Sanskrit scholars in Central Kerala, situated in the village of Deśamangalam, $35 \mathrm{kms}$. north of Trichur, in the erstwhile State of Cochin' (Sarma 1993: ix). The Vāriyam functioned in the Middle Ages as a 'college of learning', specializing in Sanskrit grammar and belles lettres (ibid.: vii). It hosted one of the largest private libraries of Kerala, whose important manuscript collection has partly been dispersed in various libraries across India, and partly lost in the heavy floods of 1907. Before this natural catastrophe, some manuscripts had been transferred to other libraries such as the Zamorin's Kovilakam in Kotțakkal, or given away to manuscript collectors like M.R. Kavi and R.A. Sastri (ibid.: xiii), which is why a number of Deśamangala manuscripts are still extant. ${ }^{21}$

Most interestingly, in the same article, Kavi acknowledges the editorial plan of T. Ganapati Sastri for the preparation of a critical edition of the Abhinavabhāratī to be published in the Trivandrum Sanskrit Series. T. Ganapati Sastri would have borrowed a MS containing chapters 9 to 19 (possibly the GOML transcript) from Kavi for his edition, which he abandoned after encounter-

the GOML quite early on, at a time where they were not properly trained in the Malayālam script.

21 For an introduction to this large manuscript collection and the old lists recovered, see Sarma 1993. Sarma is moreover credited with the identification of 285 manuscripts now in public libraries but once belonging to the Deśamangala Vāriyam collection. These were identified on the basis of the family mudrā or other indications inscribed on the flyleaves. The lists given by Sarma contain six manuscripts of the Abhinavabhäratī, but Sarma provides no evidence that any of them are now extant. To the list of the identified manuscripts can be added manuscript C. 1854 of the Abhinavabhärati $\left(=\mathrm{T}_{5}\right)$, now in Trivandrum. This manuscript contains chapters 1, 18, and 19, and bears the following indication on a flyleaf at the beginning: 'Deśamangalatta Vāriyatte Abhinavabhāratī'. The manuscript is indexed as No. 1218 (C.O.L. No. 1854) in A Descriptive Catalogue of Sanskrit Manuscripts in the Curator's Office Library, vol. 7, Trivandrum: V.V. Press Branch, Ravi Varma 1940. It is described there as belonging originally to Brahmadattan Nambūdiripāḍ from Kūtallūr, and containing 2580 granthas, which allows for its identification with the Malayālam manuscript listed as no. 126 in the Annual Report of the Department for the Publication of Sanskrit Manuscripts for the Year 1929 (= Tra. Ad. Rep. 1104.126 in NCC). As Sarma (ibid.: xiii) explains, a number of Deśamangala manuscripts had ended up in the Kūtallūr Mana, acquired as gifts, loans, pledges or by purchase. This Mana, also called Nāreri Mana, entertained privileged relationships with the Deśamanggala Vāriyam, and the Kūṭallūr Nambudiris moreover acted as their literary patrons (ibid.: xvi). 
ing difficulties with the fourth chapter (Kavi 1929: 560). Editing the fourth chapter of the Abhinavabhäratī represented an especially arduous task, no matter how good one's mastery of the Sanskrit language and familiarity with Abhinavagupta's thought. In response to De's criticism, who had moreover charged him with carrying out amateurish work, Kavi answered with a note of sarcasm: 'If Dr. De had taken a few examples from the fourth chapter and could make out anything from his copy of the commentary construing the proper text and then compared it with our edition his conclusions would have been quite contrary' (ibid.: 568). The main problem with the fourth chapter was in fact that the folios had been shuffled in several places throughout the chapter, yet simply copied out regardless of the mismatched passages. This is what Kavi had to say about the state of the fourth chapter in his preface to the editio princeps:

'A' set though fairly correct badly blundered in the fourth chapter where the scribe quietly copied leaves which had been arranged in incorrect sequence. In Malabar we frequently come across old Mss. with unnumbered leaves and if the thread gives way and the leaves get misplaced even a good scholar would feel the work of re-arrangement an arduous task. Thus for eight leaves or in 16 places the commentary breaks off and the corresponding portion is a lacuna in the other set and also in the epitome. It is here that I experienced the greatest difficulty. With the help of the Nrttaratnāvalì and Samgitaratnākara which closely follow Abhinavagupta the proper connection of the missing link in the commentary was traced and some lacuna were filled up by my own commentary based upon the two works mentioned above. ${ }^{22}$

The part where the commentary breaks off several times corresponds mainly to the technical portions of the definitions of the karanas and argahäras. However, there is also a break in the passage edited in the present book, as has been pointed out in the notes to the Edition. As to the lacunae mentioned above, Kavi took the initiative to supply his own commentary in three places where the text was wanting, and gave references to the page and line numbers in his preface, bracketing off the newly composed passages in edition. ${ }^{23}$

The first of the two sets of manuscripts mentioned by Kavi consists in the GOML transcript, whose original palm leaves came from private libraries

22 Preface to the first edition by Kavi, cited in Ramaswami Sastri 1956: 62.

23 Ramaswami Sastri (1956: 62) lists the three places as follows, with the numbering corresponding to $\mathrm{E}_{1(1)}$ : 1. page 133 , from yogāt tannäma to prayogah, 2. page 143 , lines 7 to 11 , karamāvrtta to paryastakah; and 3. from page 147 , line 24 to page $15^{2}$, line 20. 
in Malabar. The numbers and provenances of these transcripts are given by Ramaswami Sastri on the basis of the Triennial Catalogue. The second set was based on a palm leaf manuscript in Malayālam script preserved at the Palace Library in Trivandrum, a copy of which was supplied to the Sarasvati Bhavan Bhandars in Benares. A copy of this copy was supplied to the Bhandarkar Oriental Research Institute in Pune and collated with the Madras Ms. According to Ramaswami Sastri, both sets contained the same textual portions, and therefore must likely have derived from the same archetype. ${ }^{24}$ Copies of copies of these two sets of manuscripts, identified as those used by Kavi to prepare the editio princeps, were compared and partially collated by the second editor Ramaswami Sastri under the sigla Ma and Bha. ${ }^{25}$ These copies are:

- Ma $\left(=\mathrm{E}_{1(2)}{ }^{\mathrm{ma}}\right):{ }^{26} \mathrm{MS}$ No. 14049 at the Library of the Oriental Institute of Baroda $\left(=\mathrm{V}^{\mathrm{a}}\right)$. This is a transcript of chapters 1 to 7 of Ms No. 2478 at the Government Oriental Manuscript Library, Madras $\left(=\mathrm{M}_{1}\right)$.

- Bha $\left(=\mathrm{E}_{1(2)}{ }^{\text {bha }}\right)$ : $\mathrm{MS}$ No. 343 at the Bhandarkar Oriental Research Institute in Pune $\left(=\mathrm{P}_{2}\right)$. This is a copy of a manuscript at the Sarasvati Bhavan in Benares $\left(=B_{2}\right.$, collated with $\left.M_{1}\right)$, which is a transcript of an original Malayālam manuscript discovered in Trivandrum, in the library of the Maharaja of Travancore.

Although the originals of these manuscripts had already been used by Kavi in his 1926 edition, variant readings had hardly been recorded in the apparatus, and in the rare cases where this had been done, no indications of their provenance were provided. This task was assumed by the second editor. Apart from recording variants from these two transcripts whenever Kavi's text did not find support in any of them, Ramaswami Sastri also copied in his apparatus the variae lectiones listed in the text of the first edition. These readings were not preceded by a siglum, as their sources remained unidentified. Similarly,

24 Despite all their divergences, neither set transmits the commentary on chapters 7 (only partially) and 8 , and the commentary on chapter 5 is interrupted at the same place (Ramaswami Sastri 1956: 26-27). Regarding their readings, Kavi states in his preface to the first edition: 'These two sets differ in readings, but the differences are due to the erroneous deciphering of a scribe or to an intelligent suggestion of a missing word or letter where insects had damaged the leaf. However, set A closely follows Hemacandra [...], and $B$ set differs in several places and is generally less correct' (Preface by Kavi, quoted in ibid.: $62)$.

25 Ramaswami Sastri (1956: 27) also noticed that both manuscripts had been collated with other manuscripts, since they contained some different readings noted in the margins. On these variants, see below the description of the manuscripts.

26 This is the siglum assigned to this transcript - i.e. the variants listed in the apparatus by Ramaswami Sastri as 'Ma' - in the present critical edition. I could not consult directly the transcript in Baroda, but I collated here its original from Madras under the siglum $\mathrm{M}_{1}$. 
the readings preferred by Kavi but substituted by seemingly better readings found in the transcripts were moved to the apparatus without sigla. Among the other editorial principles followed was bracketing off passages taken from Hemacandra's Kāryānuśásanaviveka in the sixth chapter, ${ }^{27}$ as well as Kavi's own completion of unfinished verses; in the case of a defective text, better readings were suggested in parentheses.

Just like his predecessor, after collating the fourth chapter with the two manuscripts available to him, Ramaswami Sastri felt compelled to offer a word of caution on its unsatisfactory transmission:

The manuscript copy of B.O.R.I. Poona, though transcribed by a good hand, has still lacunae in many places and the portion corresponding to pages 166 to 184 of this edition ${ }^{28}$ has been omitted completely in the 4th chapter. Luckily this portion has been copied out from the original manuscript into the transcript preserved by the Madras Library and these readings have been taken into the foot-notes, wherever the printed portion differed from the manuscript. But the case of the Madras manuscript is quite different. Though some of the emendations of the Madras scholars and also a few other readings from mss. have been noted in the margins of the pages of the transcript it contained many errors and the copy was therefore unsatisfactory. The fourth chapter seems to have been copied out from a palm leaf manuscript, where the several folios of the manuscript were misplaced in no less than 14 places. In each place, matter to the extent of about 20 pages has been shifted from its original place to different places, either ahead or backward, so that the link of the commentary has been hopelessly broken. To re-establish this broken connection in the transcript of the commentary, which difficulty every editor or reconstructor has naturally to face, was, in this particular instance, a hard task.

RAMASWAMI SASTRI 1956: 23

27 De (1927:865) first complained in his review that Kavi had used the text of the Kāryānuś $\bar{a}-$ sana to correct or silently change some difficult passages in the sixth chapter. He himself had first edited the commentary of Abhinavagupta on the rasasütra, using the GoML transcript and a transcript of a manuscript from Trivandrum procured for him by Ganganath Jha (De 1925: 240).

28 This part corresponds to $\mathrm{ABh}$ ad Nś $4.253-282$, i.e. from the explanation of the pindïbandhas, up to the end of the portion translated here. 
Ramaswami Sastri also provided a useful table with the fourteen places where the Madras manuscript was interrupted, listing the page in his edition where the link was broken and the pages following the break in the manuscript. Though useful, this table is also quite approximate, since instead of giving the line number and last word or half-sentence before the break, it only indicates the section or name of the karana or angahära where the break occurs, for instance bhujangatrāsitam and ardhanikutțakam, where the link is first broken at the very end of the description of the karana bhujangatrāsita (p. 109, l. 11 in $\left.\mathrm{E}_{1(2)}\right)$ and continues after the first half-line in the description of the angahära ardhanikuttaka (p. 162, l. 6 in $\mathrm{E}_{1(2)}$ ). This table also records the portion missing in all the manuscripts (pp. 146-150 in $\mathrm{E}_{1(2)}$ ), which Kavi had filled in with his own commentary, although the other two places where such practice had been followed remained unnoticed. ${ }^{29}$

Ramaswami Sastri's revision work was aimed at making the editing process more transparent, though in many cases it cannot be said to have achieved its goal. Although he signalled the readings Kavi had incorporated from Hemacandra's Käryānuśäsanaviveka while editing the sixth chapter, he did not notice that Kavi had used the same text in the fourth chapter. The eighth chapter of the KAV has in fact proved an important source for the present edition, since it incorporates many passages from the discussion about the nature of dance and theatre in the section on the various genres of performance. In a few instances, Kavi's corrections or suggestions for correcting the text of the commentary coincide with readings from the KAV, most certainly because they were taken from it, although without acknowledgement. ${ }^{30}$ If this procedure is not commendable, neither is that of Ramaswami Sastri (followed by the third editor, K. Krishnamoorthy), when he decided, for instance, to simply efface Kavi's suggestion to read abhidhāyante (abhidhāya + ante) and silently corrected the manuscript reading abhidhiyante into abhidhiyate in order to match the verb with the subject in the singular. ${ }^{31}$

29 See Ramaswami Sastri 1956: 24. For passage 1 given by Kavi (p. 131, l. 9-15 in $\mathrm{E}_{1(2)}$ ), Ramaswami Sastri just brackets off a verse in a note with the indication 'etac cihnānkito bhāgo Ma. Bha. pustakayor nāsti', although the portion supplied by Kavi is longer. For passage 2 (not bracketed off in $\mathrm{E}_{1(1)} ; \mathrm{p} .141,1.7^{-11}$ in $\mathrm{E}_{1(2)}$ ), a slightly shorter passage is signalled in a note as 'Ma. etac cihnāntargato bhägo nāsti'. Passage 3 is the only one properly signalled as (p.143) 'itah parivrttakarecitā(19)ñgahāraparyantavyākhyābhāgo plutah. sampādakasya krtir iyam'.

30 For instance, the reading yad gìyate tat kasyoktirüpam, found in the KAV and retained in all editions, against yat kasyoktir iyam, given in $\mathrm{E}_{1(2)}{ }^{\mathrm{ma}}$, and the manuscript's reading, yat kasyoktirūpam, in D, $\mathrm{M}_{1}$, and $\mathrm{T}_{1}$. Cf. Edition, p. 316.

31 See Edition, p. 320. Another case where Kavi corrected the text following the KAV and 
Ramaswami Sastri based his collation work on the text edited by Kavi, which already contained his own corrections and emendations, and only recorded in the apparatus what he considered variant readings, omitting all evident scribal mistakes and other readings he could not make sense of. In this way, many of Kavi's emendations were accepted in the second and then fourth editions although they find no basis in the available manuscripts. If the readings of the manuscript are provided systematically, on the other hand, it is sometimes possible to arrive at different emendations and conjectures based on reasoning about the type of corruption, which takes into account possible confusions between akșaras that might eventually have occurred in the transition from one script to the other. When good readings are found only in Kavi's edition but not corroborated by either the available manuscripts or the KAV, we are therefore faced with a dilemma: either Kavi had better manuscripts of the Abhinavabhārati among those that could not be identified, or he was silently correcting the text with his own conjectures. ${ }^{32}$ No doubt, Kavi's knowledge of Sanskrit was finely tuned: he came from a family of Sanskrit scholars and underwent training in the Nātyaśâstra under his own father, who is said to have composed a commentary on the treatise. However, he certainly did not have all the instruments we now possess for editing the text, including a corpus of electronic texts to look for parallels, especially within the long text of the Abhinavabhäratī.33

A further revision of the second edition was commissioned to V. Raghavan, but could only be completed by K. Krishnamoorthy in 1992, since the renowned Sanskrit scholar passed away in 1979. Krishnamoorthy accepted the task since he had been persuaded by Raghavan and others that new manuscript material was available for revising the text. After collating a Devanāgari transcript of the Abhinavabhäratī acquired by the Oriental Institute in Baroda, however, he realized that he could make only minimal changes to the previous editions, and on the whole retained the improvements made in the second edition. In his own examination of previous editorial work, added to the paucity of manuscript materials, he concluded that although Kavi was virulently criticized because of his 'omissions and commissions', 'his remains the only edition up to date which records virtually all available variant readings which are significant from the

Ramasvami Sastri and K. Krishnamoorthy did not record the variant, though preferable in my opinion, can be seen at p. 324 of the Edition (cf. laukikamätrasvabhāva eva rāmanațādivyavahāravat).

32 See, for instance, Kavi's reading 'ākșiptiḍombikäprāyah, where all the manuscripts have the lacuna ${ }^{\circ} \bar{a} k s i p t a(. .) k. a \bar{a} p r a \bar{y} a h$. . Cf. Edition, p. 356. and Translation n. 245.

33 Most useful for the present work, and for any critical work on the Abhinavabhāratī, is the electronic version of the text in its entirety, prepared for SARIT (Search and Retrieval of Indic Texts). 
perspective of higher criticism' (Krishnamoorthy, Preface in $E_{1(4)}$, p. 2). On the other hand, while the second editor 'affected a good many improvements by providing full details of the critical apparatus and also very useful and informative appendices, he maintained the textual readings and variant readings intact, by and large' (ibid.).

In his re-evaluation of previous work, Krishnamoorthy was especially frustrated by the discovery that the much-awaited transcript of a new manuscript of the Abhinavabhāratī was in fact 'a scrappy summary' that did not contain anything from chapters 6 to 31, left out 'all lengthy discussions' and 'had been prepared by someone for personal use'. In a previous essay printed in his Indian Literary Theories, Krishnamoorty (1985: 141) informs us that this was a transcript of a palm-leaf manuscript found at the manuscript library in Trivandrum, which he managed to obtain after three years of negotiations. In spite of Krishnamoorty's word that the transcript is 'now available for consultation in the Oriental Institute Library' (1992: 3), I was not able to locate it on my visit to Baroda in 2012. However, I am persuaded that its original must be manuscript no. 17703 kept at the ORI in Trivandrum $\left(=\mathrm{T}_{4}\right)$, which I am tempted to identify, for reasons that I will clarify below, with the much-vaunted summary of the Abhinavabhāratī by Pūrnasarasvatīi. ${ }^{34}$ Krishnamoorthy did not describe the manuscript, since he said he was only able to consult its transcript; however, he retained some of its readings whenever he considered them valuable. Although he did not change the commentary much, he compared all of the identified parallel passages, incorporating their variant readings, especially for the sixth chapter. Among the texts he consulted for the indirect transmission of Abhinavagupta's text are the Kāryānuśāsanaviveka, in a new Keralite manuscript, the Kalpalatāiviveka, also in a Keralite manuscript, the two Sanketas on the Kāryaprakāśa by Mānikyacandra and Someśvara, a Kaumudī on the Locana kept in Madras, the Rasārnavasudhākara, and the modern Rasa Bhāva Vicāra by Kangle, not to mention the available studies of De, Raghavan, and Kulkarni, in which improvements to the text of the Abhinavabhäratī had been made.

Apart from following the previous editors in many cases without signalling it in the variants, shortcomings in this fourth revised edition are represented by cases in which the editor changed the text, possibly based on $E_{2}$ or his own intuitions, cases in which he follows $\mathrm{T}_{4}$ without acknowledging the variants of the other manuscripts, and cases in which he simply conflates two versions, as the previous editors had done.

34 The transcript, still in Baroda in 1992, might be the same as 7559 A now in Tirupati, described below as $\mathrm{T}^{\mathrm{i}}$. 
The passage edited here covers, in vol. 1, pp. ${ }^{172-184}$ in $\mathrm{E}_{1(1)}$, pp. $170-182$ in $\mathrm{E}_{1(2)}$, and pp. $168-18 \mathrm{o}$ in $\mathrm{E}_{1(4)}$.

4.2.1.2 The Madhusudan Shastri Edition $\left(=\mathrm{E}_{2}\right)$

- Vol. 1 (chapters 1 to 7 ), 1971

- Vol. 2 (chapters 8 to 18 ), 1975

- Vol. 3 (chapters 19 to 27), 1981

This edition, prepared by Madhusudan Shastri from Benares, contains the text of the Nātyaśästra and the Abhinavabhāratī with no variants, a Sanskrit commentary called (Madhusūdanī), a Hindi translation, and a Hindi commentary (Bālakrî̀ūa), which is a prose rendering of the mūla text and Abhinavagupta's commentary, with all textual problems left mostly unsolved. Among the editions consulted, the one by Madhusudan Shastri sometimes provides unexpectedly better readings, as well as consistent rearrangements of the textual materials. ${ }^{35}$ At the end of the lengthy Hindi introduction, Madhusudan Shastri says that he prepared his edition on the basis of three manuscripts: the first belonged to his guru, Śrī Bālakṛṣna, and was acquired through the intermediary of his student Gaurīśankar Śāstri from a Lingayat master; the second came from the Sarasvati Bhavan Library in Benares (possibly the same prototype of $\mathrm{E}_{1(2)}$ bha?); and the third was provided by a private owner. Despite the availability of these primary sources, Madhusudan Shastri informs us that the teachings and insights of his own master were of the utmost importance in his own constitution of the text, subtly implying that he emended the text wherever he did not find it satisfactory.

The passage edited here covers, in vol. 1, pp. 409-439.

4.2.1.3 The Nagar Edition $\left(=\mathrm{E}_{3}\right)$

- Vol. 1 (chapters 1 to 7 ), 1981

- Vol. 2 (chapters 8 to 18 ), 1984

- Vol. 3 (chapters 19 to 27), 1983

- Vol. 4 (chapters 28 to 37 ), 1984

This edition contains the full text of the Nātyaśāstra and Abhinavabhäratī prepared on the basis of the four previous editions (GOS, Kashi Sanskrit Series, Kāvyamālā, Ghosh), in addition to a good number of printing mistakes. It was published in the Parimal Sanskrit Series in Delhi. This edition has not been used here. 
4.2.1.4 The Dvivedi Edition $\left(=\mathrm{E}_{4}\right)$

- Vol. 1 (chapters 1 to 5), 1992

- Vol. 2 (chapters 6 to 11), 1996

- Vol. 3 (chapters 12 to 18 ), 2001

- Vol. 4 (chapters 19 to 27), 2004

This edition was published by Parasanatha Dvivedi at the Sampurnananda Sanskrit University in Benares $\left(=\mathrm{E}_{4}\right)$. It came out in four volumes between 1992 and 2004 and covers chapters 1 to 27 . It contains a Hindi commentary called Manoramā, composed by the editor and comprised of a Hindi translation of the text of the Nātyaśästra, one of the Abhinavabhāratī, and some comments on the Abhinavabhāratī under the name Vimarśa. As to the edited text, no variants are given for the commentary, which basically reproduces the text of $\mathrm{E}_{1(2)}$. I have therefore not deemed it necessary to collate the text of this edition, since it only contains already published material.

\subsubsection{Manuscripts}

A description of all the manuscripts of the Abhinavabhärati is beyond the scope of the present work, which offers a critical edition of a limited section of the fourth chapter based on the collation of all the available manuscripts containing it. Consequently, only the manuscripts containing the fourth chapter will be described here, and the specific features of those containing the edited fragment alone will be pointed out in greater detail while comparing the sources used and formulating some hypotheses about their relationships. To aid the reader eager to engage in further research on other chapters of the Abhinavabhāratī I first of all provide a full inventory of all the manuscripts located so far. ${ }^{36}$ This inventory lists the manuscripts in alphabetical order according to the siglum used in the edition (based on the provenance), ${ }^{37}$ the accession

$3^{6}$ The present inventory is based on the entries of the NCC, as well as some library catalogues. A useful database of the Nś and ABh manuscripts was compiled by K. Vatsyayan at the IGNCA in Delhi and given as Appendix in Vatsyayan 1996:181-208. This was also consulted, despite its many inaccuracies and duplicates. The list given here was prepared together with Daniele Cuneo during our PhD years, and was revised on the occasion of a recent collaborative work on the critical edition of the first chapter of the Abhinavabhāratī, an ongoing project that includes the critical edition of that chapter prepared by the present author and Daniele Cuneo, and a French translation of the same under the responsibility of Lyne Bansat-Boudon. A full description of all manuscript sources is planned for the introduction to the critical edition of the first chapter, for which more manuscripts have been collated.

Although not all of the manuscripts were used in the present edition, the same sigla as 
number, the chapters covered, the script and material support, and, whenever available, the date.

TABLE 3 Inventory of located manuscripts of the Abhinavabhārati

\begin{tabular}{|c|c|c|c|c|c|c|c|}
\hline & Place & Siglum $^{38}$ & $\begin{array}{l}\text { Accession } \\
\text { number }\end{array}$ & Chapters $^{39}$ & Script & Support & Date \\
\hline 1. & Adyar & A & $\begin{array}{l}\text { TR } 479 \\
(38 . G .14)\end{array}$ & 1-32 (inc.) & $\mathrm{DN}$ & Paper & \\
\hline 2. & Benares & $\mathrm{B}_{1}$ & 40765 & 1-6 (inc.) & $\mathrm{DN}$ & Paper & \\
\hline 3. & Benares & $\mathrm{B}_{2}$ & 40768 & $1-19$ & $\mathrm{DN}$ & Paper & \\
\hline 4. & Benares & $\left(B_{3}\right)$ & 40766 & $20-31$ & $\mathrm{DN}$ & Paper & \\
\hline 5. & Delhi & $\mathrm{D}$ & 148 & 1-32 (inc.) & $\mathrm{DN}$ & Paper & $\begin{array}{l}\text { Jan. } 1924 \\
\text { (Vol. 1) }\end{array}$ \\
\hline 6. & Lucknow & $(L)^{40}$ & $?$ & $\begin{array}{l}\text { (1-32 copy of } \\
\text { A) }\end{array}$ & DN & Paper & \\
\hline $7 \cdot$ & Madras & $\mathrm{M}_{1}$ & 2478 & $1-19$ & DN & Paper & 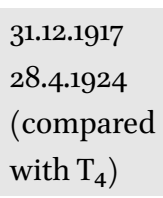 \\
\hline 8. & Madras & $\mathrm{M}_{2}$ & 2774 & 29-32 (inc.) & $\mathrm{DN}$ & Paper & \\
\hline
\end{tabular}

provided in the list have been maintained in order to create a reference system that can be followed in other works on the Abhinavabhäratī, and to avoid too many tables for the concordance of various works.

38 Most of the manuscripts have been inspected directly in India, or via the acquisition of digital copies or photocopies. The manuscripts that could not be inspected directly have their sigla in brackets.

39 The numbers of the chapters and verses in the description follow the last edition $\left(\mathrm{E}_{1(4)}\right)$, although chapter $3^{2}$ is given in the catalogues and in the manuscript as chapter 31 . All of the manuscripts have a lacuna for part of chapter 7 and all of chapter 8 .

40 The NCC records four manuscripts at Luck. Uni., p. 32, which is a list of about 200 manuscripts at Lucknow University. R.A. Sastri sent the names of a few manuscripts selected from this collection to the editors of the NCC. I had no access to this list; however, Yohei Kawajiri kindly looked for Abhinavabhāratı̄ manuscripts while in Lucknow in 2008 and found a transcript copied from the original of Adyar Library 38. G. 14 1,2. This and other Mss are not recorded in the Catalogue of Manuscripts in the Akhila Bharatiya Sanskrit Parishad Lucknow compiled by Daulat Ram Juyal. 
TABLE 3 Inventory of located manuscripts of the Abhinavabhāratī (cont.)

\begin{tabular}{|c|c|c|c|c|c|c|c|}
\hline & Place & Siglum & $\begin{array}{l}\text { Accession } \\
\text { number }\end{array}$ & Chapters & Script & Support & Date \\
\hline 9. & Madras & $\mathrm{M}_{3}$ & 2785 & $20-28$ & DN & Paper & \\
\hline 10. & Paris & $\mathrm{Pa}^{\mathrm{a}}$ & SL. $55^{41}$ & 17 & DN & Paper & $\begin{array}{l}(7 \cdot 4 \cdot 1924)^{42} \\
29 \cdot 9 \cdot 1924\end{array}$ \\
\hline 11. & Pune & $\mathrm{P}_{1}$ & $\begin{array}{l}\text { No. } 38 \text { of } \\
1916-1918 \\
\text { (342desc) }\end{array}$ & $1-3$ & DN & Paper & \\
\hline 12. & Pune & $\mathrm{P}_{2}$ & $\begin{array}{l}\text { No. } 41 \text { of } \\
1925^{-1926} \\
\left(343^{d e s c}\right) \\
{\left[=E_{1(2)}{ }^{\text {bha }}\right]}\end{array}$ & 1-32 (inc.) & DN & Paper & $\begin{array}{l}31.12 .1925 \\
\text { (copied from } \\
\mathrm{B}_{2} \text { and collated } \\
\text { with } \mathrm{M}_{1} \text { ) }\end{array}$ \\
\hline 13. & Tirupati & $\mathrm{T}^{\mathrm{i} 43}$ & $7559 \mathrm{~A}$ & $1-6$ & DN & Paper & \\
\hline
\end{tabular}

41 This manuscript is a transcript that was made for Sylvain Lévi and is now kept in his manuscript fund at the Bibliothèque de l'Institut d'Etudes Indiennes du Collège de France, Paris. I thank Ronan Moreau for sending me pictures of the first and last pages of the manuscript, at a time where the library was being moved and the manuscript was not accessible to the public.

42 This earlier date is found at the end of the manuscript with the indication 'Compared with original MS. MR J. S'. This looks like the same name and hand that had signed at the end of the first and second volumes of $\mathrm{M}_{1}$ and of $\mathrm{D}$. I believe that the copy was likely produced in Madras.

43 I came across this Ms by chance while checking out Abhinavabhāratī manuscripts on the website musicresearchlibrary.net (http://musicresearchlibrary.net/omeka/items/show/1 29, last accessed on 28.10.2019). I thank N. Ramanathan for drawing my attention to this rich corpus of online resources, including manuscripts and rare editions of musicological and dance texts. The number $7759 \mathrm{~A}$ is also assigned to this manuscript in Premalatha 2011: 'Another Paper manuscript written by Kavi bears the number 7559a titled Abhinavabhāratī and contains similar variant readings. This covers chapters $1-5$ complete and 6th incomplete. This gives a lot of commentary than 7562a'. Manuscript 7562a, also according to V. Premalatha, 'is written by M R Kavi and contains plenty of variants from different manuscripts, mentioned by him in the Preface to the I and the II editions. This covers the chapters $17-22$ complete and 23rd incomplete'. Premalatha says that in the Oriental Research Institute (ORI), Tirupati, there are manuscripts titled Nātyaśāstra/Abhinavabhāratī, but only the two mentioned above actually contain sections of Abhinavagupta's commentary. Unfortunately, I was not able to locate any record of the Abhinavabhāratī in the Descriptive Catalogue of Sanskrit Manuscripts: Kārya \& Alankāra 
TABLE 3 Inventory of located manuscripts of the Abhinavabhāratī (cont.)

\begin{tabular}{|c|c|c|c|c|c|c|c|}
\hline & Place & Siglum & $\begin{array}{l}\text { Accession } \\
\text { number }\end{array}$ & Chapters & Script & Support & Date \\
\hline 14. & Trivandrum & $\mathrm{T}_{1}$ & T. $566 \mathrm{~A} / \mathrm{B} / \mathrm{C}$ & $\begin{array}{l}\text { A: } 1-5 \\
\text { B: } 6-9 \text { (inc.) } \\
C: 29-31\end{array}$ & DN & Paper & $\begin{array}{l}13.11 .1922 / \\
5.12 .1921 / \\
14.8 .1922\end{array}$ \\
\hline 15. & Trivandrum & $\mathrm{T}_{2}$ & T. $55^{1} \mathrm{~A} / \mathrm{B}$ & $\begin{array}{l}\text { A: } 9 \text { (inc.) }-17 \\
\text { (inc.) } \\
\text { B: } 17 \text { (inc.) }-28 \\
\text { (inc.) }\end{array}$ & DN & Paper & $\begin{array}{l}10.5 \cdot 1922 \\
20.5 \cdot 1922\end{array}$ \\
\hline 16. & Trivandrum & $\mathrm{T}_{3}$ & T. 259 & 1 (inc.), 18,19 & DN & Paper & \\
\hline 17. & Trivandrum & $\mathrm{T}_{4}$ & 17703 & $1-6$ & Mal & Palm leaf & \\
\hline 18. & Trivandrum & $\mathrm{T}_{5}$ & C. 1854 & $1,18,19$ & Mal & Palm leaf & \\
\hline 19. & Trivandrum & $\mathrm{T}_{6}$ & 20410 & 1-19 (inc.) & Mal & Palm leaf & \\
\hline 20. & Trivandrum & $\mathrm{T}_{7}$ & 20411 & 1-14 (inc.) & Mal & Palm leaf & \\
\hline 21. & $\begin{array}{l}\text { Trippuni- } \\
\text { thura }\end{array}$ & $\mathrm{T}^{\mathrm{r}}$ & B. 239 & 6 & Mal & Paper & \\
\hline 22. & $\begin{array}{l}\text { Vadodara/ } \\
\text { Baroda }\end{array}$ & $\mathrm{V}^{\mathrm{a}}$ & $\begin{array}{l}14049 \\
{\left[=\mathrm{E}_{1(2)}^{\mathrm{ma}}\right]}\end{array}$ & $1-7$ & DN & Paper & 1946 \\
\hline 23. & $\begin{array}{l}\text { Vishakha- } \\
\text { patnam }\end{array}$ & $\mathrm{V}^{\mathrm{i}}$ & 249 & 1 & Tel & Paper & \\
\hline
\end{tabular}

4.2.2.1 Manuscripts Containing the Fourth Chapter

A Adyar Library, Madras/Chennai. MS TR 479 (1-4). Paper. Devanāgarī script. Described in the seventh volume of the library's Descriptive Catalogue of Sanskrit Manuscripts (Sarma 2015: 106-107). Dimensions as per catalogue: $21 \times 16.5 \mathrm{~cm}$. The catalogue lists chapters 1 to $29,1,373$ pages, but on direct inspection, the chapters are 1 to (31)32 (incomplete) and the number of pages 2,073. Lined paper, with 15 lines to a side. Bound in 4 volumes. Other identifiers found on the manuscript are 63557; XXIX D 11 (1-4). This manuscript is indexed under number 38.G.14 in A Catalogue of the Sanskrit Manuscripts in the Adyar Library, Part II, p. 46 (Chintamani

of the Tirupati Sri Venkateswara University Oriental Research Institute (Ramamurthi \& Matha 1993), nor in the Alphabetical Index of Sanskrit Manuscripts in the Rashtriya Sanskrit Vidyapeetha Manuscripts Library, Tirupati (Govindan et al. 2003). 
1928b) under the title Bharataśāstravyākhyā (Abhinavabhāratī), 2079 granthas.

Vol. 1: chapters 1 to 4.

Chapter 4: pp. 127-408. Edited passage: pp. 196-202, 318-350.

Vol. 2: chapters 5 to 14. Pages are numbered 1 to 700 for chapters 1 to 6. After chapter 6 there are a few blank pages, then foliation starts anew with chapter 7 .

Vol. 3: chapters 15 to 23. Page numbers continue from vol. 2 .

Vol. 4: chapters 24 to (31)32. Page numbers continue from vol. 3, up to 1,373. End: atrāpi pratāpahlādakatvaśaighrāyavāntaraṃ rājāder anyesyam evam sarvatra grahājīnādayah, uktavrșagās trivyādayah kālā iti śasyagāhuh, harih om. This is marked as chapter 31, but it actually corresponds to ABh ad Nś 32.351-352, vol. 4, pp. 377-378. Incomplete.

Notes: The fourth chapter contains indications about a manuscript having different readings at the places where the text breaks. Some of them refer to the 'manuscript of Govindadas of Vizagapatam'.

$\mathrm{B}_{1} \quad$ Sampurnanand Sanskrit Visvavidyalaya, Sarasvati Bhavan Library, Benares. MS 40765. Paper. Devanāgarī script. Described in A Descriptive Catalogue of the Sanskrit Manuscripts, Acquired for and Deposited in the Sanskrit University Library (Sarasvati Bhavana), Varanasi, during the years 17911950, Vol. XI of 1964, pp. 30-31. Dimensions as per catalogue: $8.6 \times 13.5$ inches $(=21.8 \times 34.3 \mathrm{~cm})$. Feint-lined paper, with 28 to 30 lines to a side. Chapters 1 to 6 (incomplete). 18 o pages.

Chapter 4: p. 57 to 146. Edited passage: not transmitted.

Ends abruptly after six pages of chapter 6: gāndharvavede gitakaviśeșe devanakāadiśabdah tad etad uktam (= ABh ad Nś 6.12-13).

Notes: It gives the pratīkas for the verses of the Nś with numbering. The MS is lacunose, but signals lacunae with dots.

$\mathrm{B}_{2} \quad$ Sampurnanand Sanskrit Visvavidyalaya, Sarasvati Bhavan Library, Benares. MS 40768. Paper. Devanāgarī script. Described in A Descriptive Catalogue of the Sanskrit Manuscripts, Acquired for and Deposited in the Sanskrit University Library (Sarasvati Bhavana), Varanasi, during the years 17911950, Vol. XI of 1964, pp. $3^{2-33}$. Dimensions as per catalogue: $8.6 \times 12.5$ inches $(=21.8 \times 31.7 \mathrm{~cm})$. Feint-lined paper, with 18 lines to a side. Chapters 1 to 7 and 9 to 19 .

On the front page of the manuscript, the chapters and number of pages are indicated. Chapter 7 is marked as 'incomplete' and chapter 8 as missing (nāsti). The numeration is continuous until chapter 14, p. 463, after 
which chapters 15 to 17 are marked as 'supplied', and the numeration continues from chapter 18, p. 467, up to p. 620 .

Chapter 4: pp. 61-165. Edited passage: not transmitted.

Notes: The first four pages contain the beginning of chapter 1 up to $y \bar{a}$ gatir dānaśīlānām tām gatim prāpnuyāt tu saḥ || iti || These pages are not numbered and are written by a different hand. They are prefaced with an indication written in pen: 'Addenda to the volume of Abhinavabhärati sent by Mr. Govinda D.' After the change of pen and layout, numeration starts on p. 1 with ti. etena 'kämajo daśako guna' iti. The Ms is lacunose, but signals lacunae with dots. Sometimes a more complete text is added on top of the line in which the lacuna has been signalled.

D National Archives, Delhi. MS 148, 3 parts. Listed in the List of Sanskrit Manuscripts in National Archives of India. Paper. Devanāgarī script. Lined paper, with 24 lines to a side. Chapters are 1 to (31) 32 (incomplete).

First part: Chapters 1 to 6, pp. 1-311; at the end, written in a different hand: 'Compared with Original Mss MR. JS.'

Second part: Chapters 7 (incomplete) and 9 to 19, pp. 1-319

Third part: Chapters 28 to 32, pp. 1-246. On p. 106, the text is interrupted: rudrasyānucaro bhütveti kecit. tasyārthasya. (ABh ad Nś 28.11, vol. 4, pp. $7-8)$. After that, written in a different hand: atah prabhrti adhyāyaparyantam mātrkāyaṇ̃ luptam. Written in a third hand: 'Compared with Original MSs MR. JS 23.1.24.' The text ends on page 246: atrāpi pratāpahlādakatvaśaighrādyavāntaram rājer anyeșyam evam sarvatra grahājīiādayaḥ, uktavrșagās trivyādayaḥ kāāa iti śasyagāhuḥ. (ABh ad Nś 32.351$35^{2}$, vol. 4, pp. 377-378). Written in a fourth hand: 'Compared with Original MSs JS., MR 15.5.24.'

Chapter 4: pp. 127-408. Edited passage: pp. 102-107, 154-172.

Notes: This manuscript is not recorded in the database by Kapila Vatsyayan. It incorporates different readings by bracketing them off after the original reading. Moreover, it features corrections in red by a second hand, thus indicating redactional activity.

$\mathrm{M}_{1}$ Government Oriental Manuscripts Library, University of Madras, Chennai. MS R. 2478. Paper. Devanāgarī script. Described in A Triennal Catalogue of Manuscripts Collected During the Triennium 1916-17 to 1918-19 for the Government Oriental Manuscript Library, Madras, Volume III, Part 1, Sanskrit B (Sastri 1922: 3477-3480). Dimensions as per catalogue: 10.7/8 inches, $9.5 / 8$ inches $(=27.6 \times 24.5 \mathrm{~cm}), 271$ folios. Feint-lined paper, with 20 lines to a side. Chapters 1 to 19, bound in two volumes. Transcribed in 1917- 
1918 from a MS. of M.R. Ry. Ampalakāt Karuṇākara Menon of Chalapuram, Calicut.

Vol. 1: chapters 1 to 6, pp. 1-275.

Chapter 4: pp. 64-167. Edited passage: pp. 90-93, 132-145.

Vol. 2: chapters 7 (incomplete) and 9 to 19 , pp. $276-543$.

Notes: At the end of volume 1, on p. 275, in blue pen, 'Compared with original MSs', signed 'MR 15.1.18'. The following lines are also found on the same page: 'Compared with the Ms of Mr. Govindadas of Vizagapatnam Benares. Transeribed from the Ms. of M. R. Ry. Ampalakat Karunakara Menon of Chalapuram, Calicut in 1917-1918. Compared with a different MS on laned (sic.) from Manavikrama Anujan Kunjunni Raja Second Raja Calicut'.44 Two dates are found near this note, the first being 31.12.17, signed ' $\mathrm{M}$ ' (?), and the second 28.9.24, bearing a different signature.

It is possible that another manuscript was consulted in 1924, hence after the date of publication of the 1922 catalogue and most probably before that of the 1926 editio princeps, which incorporates its variants. In the manuscripts, a number of corrections and marginal additions is in fact added in blue pen and, from page 3 , in red pen. It appears that GOML 2478 was on loan for a certain period (at least since 1921, the date of the record of its variants in $\mathrm{T}_{1}$, on which see below) at the Curator's Office in Trivandrum, as recorded in vol. 7 of A Catalogus of Mss. Collected by the Curator for the Publication of Sanskrit Manuscripts, Trivandrum, by T. Ganapati Sastri, (1923). (= Triv. Cur. 137 in the NCC). The entry is listed as 'Abhinavabhäratī (Nätyavedavivrti), [name of the person or library from which the manuscript was obtained] Mr. M. Ramakrishna

The same name appears as the owner of a manuscript containing the first 19 chapters of the Abhinavabhäratī, recorded in 1923 in vol. 7 of A Catalogue of Mss. Collected by the Curator for the Publication of Sanskrit Manuscripts, Trivandrum, by T. Ganapati Sastri (1923) (= Triv. Cur. 138 in the NCC). The manuscript is said to belong to 'Anujan Kunjunni Tampuran, Second prince, Calicut, Malayalam, 9000 granthas, àditạ 19 adhyāyāḥ'. This could have been the original Malayālam manuscript on which the copy of $\mathrm{M}_{1}$ was based. It is reasonable to assume that the change in name in vol. 1, from 'M. R. Ry. Ampalakat Karunakara Menon of Chalapuram, Calicut' to 'Manavikrama Anujan Kunjunni Raja Second Raja Calicut', must be due to a change in ownership of the Ms between 1922 (the date of the Sastri catalogue) and 1923, when the manuscript was in the Curator's Office, as recorded by T. Ganapati Sastri. Moreover, 'Manavikrama Anujan Kunjunni Rajha 3rd Raja Calicut' appears as the owner of the original of vol. 2 of GOML 2478, dated 1917-1918, which means that he must have been upgraded to 'Second Raja' between 1918 and 1923, following the succession system of the Zamorins of Calicut, on which see Haridas 2016. 
Kavi, Madras, Devanagari, 5000 granthas, 1-adhyāyaikadeśam ārabhya 19 adhyāyāntam'.

At the end of volume 2, on p. 543, the following is written:

'Copied J. S. (?) 31.1.18'. 'Copied in 1917-18 from a Ms. of Manavikrama Anujan Kunjunni Rajha 3rd Raja Calicut'. In blue pen, there is written 'Compared with original Mss.' and signed 'MR 31.1.18'; and 'Compared also with the Manuscript of Mr. Govindadas of Vizagapatnam Benares', signed 'M (?) 3.2.18'. Another signature prints 'M.A. J. 3.2.18'.

$\mathrm{P}_{2} \quad$ Bhandarkar Oriental Research Institute, Pune. MS 41 of 1925-1926 (343 desc). Paper. Devanāgarī script. Lined paper. Chapters 1 to $(31) 32$ (incomplete). Feint-lined paper, with 21 lines to a side. Described in the Descriptive Catalogue of the Government Collections of Manuscripts Deposited at the Bhandarkar Oriental Institute, vol. XII, Alamkāra, Samgìta and Nātya, Gode 1936. Dimensions as per catalogue: $8.3 / 8 \times 13.3 / 8$ inches $(=21.3 \times 34)$. Feint-lined paper, with 28 to 30 lines to a side. 539 pages.

Chapter 4: pp. 42-93. Edited passage: not transmitted.

Notes: Written on the front page: 'This MS. is copied from the MS. in the Benares Sanskrit Library by Ganesh Narhar Shrigondekar. B.A., Bhandarkar Oriental Research Institute Poone (India). Tuesday 31st December 1925'.

On the back of the front page, the anukramanika gives the following information: chapter 7 is incomplete, chapter 8 is not given, chapter 22 has no ending, chapter 23 has no beginning, and chapter 31 is incomplete (this is actually chapter 32 in Kavi's edition and has the same ending as A and D).

Written on the same page after the anukramanikā: 'N.B. This manuscript is copied from the Ms. in Benares Library. The MS. in Benares Library was copied at Trivandrum and subsequently collated with a Ms. in the Government Oriental Library, Madras. The Benares Ms. consisted of two volumes, first being a bound one containing 620 pages with additional loose 92 pages placed in several chapters. All these contained 19 chapters out of which 8 th not being found. The second volume contained two loose sets of 78 and 189 pages. This contained next 12 chapters, the last is 31 st being incomplete'.

$\mathrm{T}_{1} \quad$ Oriental Research Institute, Trivandrum. Ms T 566A/B/C. Paper. Devanāgarī script. Lined paper. Chapters 1 to 4, 5 to 9 , and 29 to 31 . Paper, with 20 lines to a side. Described as No. 1216 A\&B/C (c.o.L. No. 566/C.O.L. No. 566 C) in A Descriptive Catalogue of Sanskrit Manuscripts in the Cur- 
ator's Office Library, vol. 7, Trivandrum:V.V. Press Branch, Ravi Varma 1940 (= TDC $1216 \mathrm{~A} \& \mathrm{~B}+\mathrm{C}$ ). Dimensions as per direct inspection: $22 \times 35 \mathrm{~cm}$ (the catalogue gives $8.1 / 4 \times 13.1 / 2$ inches).

$\mathrm{T} 566 \mathrm{~A}+\mathrm{B}=$ No. $1216 \mathrm{~A} \& \mathrm{~B}=\mathrm{COL} 566$ (From Curator's Office), chapters 1 to 9 (incomplete). 6000 granthas. Continuous foliation: $1-53$ o. End: paripatanam vāto cakraṃ vakratvam maṇdalam vartulatvam (ABh ad Nś 9.67 , vol. 1, p. 42).

Chapter 4: pp. 118-297. Edited passage: pp. 235-264.

T $566 \mathrm{C}=$ No. $1216 \mathrm{C}=\mathrm{COL} 566 \mathrm{C}$ (From Curator's Office), chapters 29 to $(31) 32$ (incomplete; same ending as $\mathrm{A}, \mathrm{D}$, and $\mathrm{P}_{2}$ ). 3300 granthas.

Notes: The manuscript is actually the beginning of the edition that was being prepared by T. Ganapati Sastri. The first 8 pages are printed and bear the date 29.3.1998, i.e. 13.11.1922. The rest is in manuscript form and gives the text of the Nätyaśästra on the top half of the page and the Abhinavabhāratī on the bottom half. It offers an apparatus with variants for the müla text and commentary, variously given with unidentified sigla: 'ka', 'kha', 'ga' ... The identification of the manuscripts used in the collation must await the future examination of a broader portion; however, for a few hypotheses concerning the portion edited here, see below. In the fourth chapter, the continuity of the text has been restored by arranging the displaced pages in the right order and subsequently renumbering them (the pagination is changed in several places). The first pages of the fourth chapter (pp. 118-158) are edited in red and black pen, and an apparatus of variants written in red pen. Thereafter (pp. 159-169), corrections are made only with a black pen and the apparatus is missing for the commentary. ${ }^{45}$ The text continues with corrections in blue (pp. 170-199), black (pp. 200-232), blue (pp. 233-239), and again in black pen until the end (pp. 240-297).

$\mathrm{T} 566 \mathrm{~A} / \mathrm{B}$ ends abruptly (the text will continue in $55^{\mathrm{A}} \mathrm{A}$ ), after which, on page 531 (unnumbered), it is written in Malayālam that what follows are variants from the manuscript of the Abhinavabhāratī at the Oriental Institute in Madras.

On page 532 (unnumbered): a date is written as 5.12.1921 at the top left of the page, followed by series of variants ( $p$ atthabheda), listed with prștha (page) and pankti (line) according to $\mathrm{T}_{1}$. This continues for 5 pages. Then there is a page marked ' 1 ' at the top right, and 'prșțam 46, panktih 93' at 
the top left: hastābhyām athetyādinā yat paścāt svastikākhyam karanam. In the middle of page 4 , another list of variants resumes. The next page restarts the numeration from 1 , and again contains a long variant text, starting with pādasvastikabhramaṇād dehasya sākṣätkrtaḥ| saṃñāyām $k a n$. As far as I could verify, as concerns the passage edited here, the variants given at the end of $T 566 \mathrm{~B}$ correspond to the text of $\mathrm{M}_{1}$, without the additions of $\mathrm{T}_{4}{ }^{46}$

On the last page of variants, written in the same red pen as the variants, is written 'E.R. Krishnamacharya Sanskrit Pandit G.O. Mss Library Egmore Madras'.

On the very last page of the manuscript is written 'Manavikrama Anujan Kunjunni Raja 3rd Raja Kalikut'.47

At the end of $\mathrm{T} 566 \mathrm{C}$, written in blue pen, is 'Compared with Original A.S. Charī 14.8.22 M.K. Srirangachariar'.

$\mathrm{T}_{4} \quad$ Oriental Research Institute, Trivandrum. Ms 17703. Palm leaf. Malayālam script. Chapters 1 to 6 and $3^{1}$ to 37. Described in the Alphabetical Index of Sanskrit Manuscripts in the University Manuscripts Library, vol. 6, Supplementary, Trivandrum: University of Kerala, Vijayan et al. 1995. Dimensions as per direct inspection: $39 \times 4.5 \mathrm{~cm} .7500$ granthas.

The manuscript has two parts, written in different hands. The first part covers chapters 1 to 6 (incomplete), the second chapter $3^{1}$ (incomplete) to 37 .

Fourth chapter: 14V2-2or3. Edited passage: 14V2-17r8.

Ends in chapter 6: etan neti śrīśankukah.

The second part of the Ms starts on f. 34 with ABh ad Nś 31.140. The foliation starts anew with harih and the numeral ' 1 ' in Malayālam letter numerals written in the left margin.

Colophon of the Ms: nārāyanalikhitam idam pustakam. Kātțumātam.

Written on the wooden cover: '16g' (possibly the Ms no. of the Kātțumāṭam group donated to the library). ${ }^{48}$

46 These variants have been labelled as $\mathrm{T}_{1}{ }^{\mathrm{vl}}$ in the apparatus of the present edition. They were most probably recorded in $\mathrm{T}_{1}$ at the time when the manuscript GOML 2478 was on loan for a certain period at the Curator's Office in Trivandrum, on which see the notes on $M_{1}$ above.

47 This must correspond to the owner of the $\mathrm{MS}$ with the variants, i.e. $\mathrm{M}_{1}$, that were incorporated by Krishnamacharya in Trivandrum.

48 On the Kāțumāțam illam, famous for its practice of mantravāda, see Parpola 1999: 181182. I am grateful to Christophe Vielle for this reference and for his invaluable help in 
$\mathrm{T}_{6}$ Oriental Research Institute, Trivandrum. MS 20410. Palm leaf. Malayālam script. Chapters 1 to 19 (incomplete). 130 folios. Described as n. 1404 in A Descriptive Catalogue of the Sanskrit Manuscripts in H.H. the Maharajah's Palace Library, vol. 7, Trivandrum:V.V. Press Branch, Sambasiva Sastri 1938. Dimensions as per direct inspection: $55 \times 5 \mathrm{~cm}$ (the catalogue gives $22 \times 2$ inches, 130 leaves, 8 lines per page).

Chapters 1, 2 (incomplete) and 4 to 19 (incomplete). $675^{\circ}$ granthas.

Chapter 4: 19r5-42v5. Edited passage: not transmitted.

End of manuscript: ABh ad Nś 19.97.

$\mathrm{T}_{7}$ Oriental Research Institute, Trivandrum. MS 20411. Palm leaf. Malayāḷam script. Chapters 1 to 14 (incomplete). 118 folios. Described as n. 1404 in A Descriptive Catalogue of the Sanskrit Manuscripts in H.H. the Maharajah's Palace Library, vol. 7, Trivandrum:V.V. Press Branch, Sambasiva Sastri 1938. Dimensions as per direct inspection: $53.5 \times 5 \mathrm{~cm}$ (the catalogue gives $21.5 \times 2$ inches, 118 leaves, 10 lines per page).

Chapters 1 to 14 (incomplete). 5300 granthas.

Chapter 4: 19vio-46vg. Edited passage: not transmitted.

End of manuscript: ABh ad Nś 14.1.

Notes: Lacunae are signalled with added spaces in this MS.

$\mathrm{T}^{\mathrm{i}} \quad$ Tirupati ms 7559A. Paper. Devanāgarī script. Chapters 1 to 6 (incomplete). 63 pages. ${ }^{49}$

$V^{a} \quad$ Vadodara/Baroda MS 14049. Paper. Devanāgarī script. Chapters 1 to 7 (incomplete). These data are given by Ramaswami Sastri in his preface to the second edition, while in the Alphabetical List of Manuscripts in the Oriental Institute, Baroda, vol. II (Nambiyar \& Nyāyabhūṣaṇa 1950: 1112), there is a manuscript listed as no. 152 in the Alamkāra section under the label Bharatanātyaśāstravyākhyā 'Abhinavabhāratì', with the accession number 13282. This manuscript is said to consist of 137 leaves and 2250 granthas, and to contain only chapters 18 and 19, which does not correspond to the transcript collated by Ramaswami Sastri.

discussing details about Keralite manuscripts, as well as for providing me with PDFs of hard-to-find manuscript catalogues and lists.

49 I have been able to view this manuscript only online (http://musicresearchlibrary.net/ omeka/items/show/129). The microfilm, made on 4 August 1986, is unfortunately almost illegible. For more on the history of this manuscript, see above, n. 43 . 


\subsubsection{Relationship between the Manuscripts}

Among the twelve manuscripts containing the fourth chapter, only seven contain the passage edited in this book, namely $A, D, M_{1}, T_{1}, T_{4}, V^{a}$, and $T^{i}$. The others, i.e. $\mathrm{B}_{1}, \mathrm{~B}_{2}, \mathrm{P}_{2}, \mathrm{~T}_{6}$, and $\mathrm{T}_{7}$, are all interrupted before the start of the passage and have a lacuna covering ABh ad NŚ 4.253-282, as was noticed by Ramaswami Sastri for Ms Bha $\left(\mathrm{E}_{1(2)}\right.$ bha $)=\mathrm{P}_{2}$. Among these two groups, a number of relationships can be identified on the basis of common omissions, conjunctive errors, ${ }^{50}$ marginal notations, lacunae and repetitions.

In the first group of manuscripts, $\mathrm{T}_{1}$ and $\mathrm{T}_{4}$ (and $\mathrm{T}^{\mathrm{i}}$, which I consider its copy) stand alone, for reasons I explain below. The other manuscripts can thus be grouped into two sets, which correspond to the A and B sets described by Kavi, i.e. the Madras and the Trivandrum sets:

A) To the Madras set belong manuscripts $A, D, M_{1}$, and $V^{a}$.

B) To the Trivandrum set belong manuscripts $\mathrm{B}_{1}, \mathrm{~B}_{2}, \mathrm{P}_{2}, \mathrm{~T}_{6}$, and $\mathrm{T}_{7}$.

Regarding group A), manuscripts $\mathrm{A}, \mathrm{D}$, and $\mathrm{V}^{\mathrm{a}}$, can safely be considered to be copies of $\mathrm{M}_{1}$. Ramaswami Sastri already informs us that $\mathrm{V}^{\mathrm{a}}$, the manuscript $\mathrm{Ma}$ he used to re-edit the text $\left(=\mathrm{E}_{1(2)} \mathrm{ma}\right)$, is a transcript of $\mathrm{M}_{1}$, produced in 1946 . As to $A$, it also appears to be a direct copy of $M_{1}$, since it features the same breaks in chapter 4 and even provides the same indications about the different readings of another manuscript that was compared with $\mathrm{M}_{1}$, the one of Govinda Das, to which I will return below.

The breaks in the text of $\mathrm{M}_{1}$ are signalled in the left margin when they occur, and the page where the text continues after the interruption is also indicated there. This has indeed been very helpful in establishing some relationships of filiation between the manuscripts. The following can be given as evidence for A being a copy of $\mathrm{M}_{1}$ :

- When the text is interrupted the first time in $\mathrm{M}_{1}$, on p. $81,1.14$, one reads in the left margin: 'see of the pg. 84 for different reading'. The break is as follows:

1. 13: pātayec cāgrayogena ... [sā sūcī] (added with a different pen) $\left[\mathrm{E}_{1(2)}\right.$, p. $105,1.8]^{51}$

$5^{\circ}$ I use 'conjunctive error', in Paul Maas's terminology, as 'an error common to B and C of such a nature that it is highly improbable that $\mathrm{B}$ and $\mathrm{C}$ committed it independently of each other', as quoted in Pecchia 2009-2010: 128, n. 33.

51 The first break is indicated by Ramaswami Sastri as on p. 109; however, a direct inspection of $\mathrm{M}_{1}$ reveals that it is actually on p. 105, l. 8 of his edition that the link is first broken. The same should be corrected in the indication of the continuing passage after the second break, i.e. ' 2 After the Break on 166 are found pages 109-119'. Pp. 105-119 should be listed instead. 
l. 14: litam krtveti nūpurapādam. dūtam ākṣiptetyādinā vivrttam karaṇam ihākșiptam hastapādam ca [tritạ̣ caiva] (added with a different pen) vipattitam $\left[\mathrm{E}_{1(2)}\right.$, p. 162, l. 6-8]

The same reading can be found in A, p. 161, l. 12, with the number of pages indicated in the left margin changed accordingly: 'See on the page 169 for different reading'

l. 12: pātayec cāgrayogena ... (sā sūcī) (bracketed to mark the addition in $\left.\mathrm{M}_{1}\right)\left[\mathrm{E}_{1(2)}\right.$, p. 105, l. 8]

1. 13: litạ̣ krtveti nūparapādam. dūtam ākṣiptetyādinā vivrttam karaṇam ihākșiptam hastapādam ca tritạ̣ caiva ... [p. 162, l. 1] vipattitam $\left[\mathrm{E}_{1(2)}\right.$, p. 162, l. 6-8]

- Similarly, on p. 84b, the first two lines in $\mathrm{M}_{1}$ read: 'Different readings found in the MS. of Govindadas of Vizagapatam (from 14th line of 81st page to 84th page)'.

The text continues on p. 84b from the interruption on p. 81: ardha ūrdhvaśabdena dvit̄̄yasmin pāde sūcī kāryā. $\left[\mathrm{E}_{1(2)}\right.$, p. 105, l. 9]

Again, A adds the same reference, with pages indicated according to manuscript A. On p. 169, l. 11: 'Different readings found in the Ms. of Govindadas of Vizagapatam (from 13th line of 161st page to 169th page)'.

- References to the MS of Govindadas are similarly found in $\mathrm{M}_{1}$ on:

p. 88a: 'different readings found in the M S of Govindadas of Vizagapatnam from 13th line of 89th page to 6th line of 95th page';

p. 108a: 'Different readings found in the MS of Govindadas of Vizagapatam from 2nd line of 109th page to 4 th line of $147^{\text {th }}$ page'.

The same breaks and the same references to the MS of Govindadas are found in A:

p. 185, 1. 5: 'Different readings found in the Ms of Govindadas of Vizagapatam from 7 th line of $185^{\text {th }}$ page to 1oth line of 193rd page';

p. 234: 'different readings found in the MS of Govindadas of Vizagapatnam from $15^{\text {th }}$ line of 234 page to ... page'.

- On A p. 235, l. 13, in the left margin, '108-b' is written, which corresponds to p. $108 \mathrm{~b}$ in $\mathrm{M}_{1}$.

Manuscript A should therefore be considered a copy of $\mathrm{M}_{1}$, and this is the reason why it has not been considered for the present edition, just as $V^{a}$.

As to manuscript D, I have examined it directly at the National Archives of India in Delhi. Whereas $\mathrm{M}_{1}$ signals the interruption of the text in the margins, D signals it by writing 'nātra granthapātah', then divides the page into two parts with a line, printing the text after the interruption in $\mathrm{M}_{1}$ at the top, and the text as it should have followed continuously at the bottom, marking it as 'pāthāntaram'. This pāthāantara corresponds to the text of $\mathrm{M}_{1}$ as it is given after 
the interpolated passages, and helps the reader to restore the continuity of the text. ${ }^{52}$ Although it looks like a copy of $\mathrm{M}_{1}$ with a different layout in which the text is interrupted, I have nevertheless included D in the collation to show how, most of the time, it incorporates the additions of the second hand in $\mathrm{M}_{1}$. These additions (written in faded blue ink in $\mathrm{M}_{1}$ ) are placed in brackets in $\mathrm{D}$ after the reading of the prima mano (though not systematically; sometimes $\mathrm{M}_{1}{ }^{\text {sm }}$ is just incorporated into $\mathrm{D}$ without marking it off from the main text). Where the correction in $\mathrm{M}_{1}$ is inserted by the prima mano (a normal ' $p c^{\prime}$ ), $\mathrm{D}$ just transcribes the corrected version. In very rare cases, when the readings in $D$ differ from $M_{1}$, I suspect that they might have been corrected with the help of the edition or another manuscript, especially when the correction is suggested above the line and in brackets. $D$ does not seem to incorporate the variants in $M_{1}$ that correspond to $\mathrm{T}_{4}$, more on which see below.

The constitution of $\mathrm{M}_{1}$ deserves more detailed treatment, since this manuscript features clear signs of contamination or horizontal transmission. ${ }^{53}$ As mentioned above, this transcript incorporates corrections by the copyist and additions in blue pen and red. These were not recorded in the incipit of the 1922 catalogue by Sastri, but they were recorded in $E_{1(1)}$ and should therefore give us some hints about the manuscripts that were used by Kavi. The variants in $\mathrm{M}_{1}$ indeed correspond to the readings of $\mathrm{T}_{4}$. For instance, sarvaśaktimayam in the third mangala verse in chapter 1 is corrected in the manuscript to dhartríaktimayam $\left(\mathrm{M}_{1}{ }^{\mathrm{sm}}\right)$, which corresponds to the reading of $\mathrm{T}_{4}$. Although not recorded in Sastri's catalogue, this reading was accepted by Kavi in his edition, whereas he prints sarvaśaktimayam in the apparatus as a variant of Ka $\left(=\mathrm{E}_{1(1)}{ }^{\mathrm{ka}}\right)$. The same holds for the reading tadupajñam pravrttir in $\mathrm{M}_{1}(\mathrm{ABh}$ ad Nś 1.1, vol. 1, p. 2), printed as such in the catalogue but corrected to tadupajñam tāndavapravrttir in $\mathrm{M}_{1}{ }^{\mathrm{sm}}$. The original reading of $\mathrm{M}_{1}$ is retained in Kavi's edition and the reading tanndavapravrttir is printed in the apparatus as $\mathrm{E}_{1(1)}{ }^{\mathrm{sa}}$. Another hint to the fact that a manuscript corresponding to $\mathrm{T}_{4}$ must have been compared with $\mathrm{M}_{1}$ in April 1924 - the date recorded at the end of the first part of $\mathrm{M}_{1}$-is that its variants are not recorded in $\mathrm{D}$, which is a transcript of $\mathrm{M}_{1}$ that bears January 1924 as the date of the copy. It remains unclear whether the comparison with $\mathrm{T}_{4}$ was undertaken in Trivandrum, where $\mathrm{M}_{1}$ seems to have been on loan between 1921 and 1923 (cf. n. 46), or in Madras, after the manuscript was

$5^{2}$ The list of the disconnected portions in the text of the fourth chapter provided in Ramaswami Sastri 1956: 24 has also proven useful in dealing with manuscript D.

53 On these and other technical terms in textual criticism, see, e.g., the carefully designed introduction to the critical edition of the Nyāyamañjari in Graheli 2015, as well as Pecchia 2009-2010. 
returned to the GOML, though the date 28.4.24 at the end of $\mathrm{M}_{1}$ would plead for the latter assumption.

For the portion edited in this book, the secunda mano of $\mathrm{M}_{1}$ does not seem to provide the variants of $\mathrm{T}_{4}$ as in the first chapter, save for a few exceptions, but possibly the corrections made by comparison with the original Malayālam manuscript or with a manuscript close to $\mathrm{T}_{1}$, since in many cases $\mathrm{M}_{1}{ }^{\mathrm{sm}}$ corresponds to its readings. The manuscript of Govinda Das, also mentioned in the colophon of $\mathrm{M}_{1}$, is certainly part of group $\mathrm{B}$, which does not showcase the relevant passage of the Tändavādhyāya. Hence, the secunda mano of $\mathrm{M}_{1}$ in the passage edited here certainly does not include variants from this manuscript.

As already pointed out, $\mathrm{T}_{1}$ represents the beginning of an edition containing variant readings, although for the passage that concerns us here, $T_{1}$ provides no apparatus, but only corrections made directly to the text, which I chose to signal as $\mathrm{T}_{1}{ }^{\mathrm{pc}}$, since it is difficult to decide whether this is a second hand. $\mathrm{T}_{1}{ }^{\mathrm{pc}}$ appears to have been corrected largely based on a manuscript similar to $\mathrm{M}_{1}$, even in cases where the reading in $\mathrm{T}_{1}{ }^{\text {ac }}$ was clearly better, possibly representing a work still in progress, where the corrections do not necessarily represent the chosen variant but simply the collation, though not done systematically. In many cases, its readings correspond to the text of $\mathrm{T}_{4}$, either as unique readings or before correction. In other cases, $T_{1}$ offers readings that are not found in other manuscripts, a few of which present a more readable text and have thus been retained against other testimony. It is unfortunately impossible, given the present state of the available sources, to decide with any certainty whether T. Ganapati Sastri was using better manuscripts for his edition that are no longer available (possibly the original Malayālam manuscript of $\mathrm{M}_{1}$ ?), or if the scribe in charge of the transcript had sufficient knowledge of the text to silently correct it when the original did not make sense. An example in point is the following variant: gìtakārtheti gïteșv] $\mathrm{T}_{1}^{\text {ac }} \Sigma \mathrm{E}$, gïtakärtheti gìterșy $\mathrm{D}$ $\mathrm{M}_{1} \mathrm{~T}_{1}{ }^{\mathrm{pc}}$, gittakārthe 'bhihitess $\nu \mathrm{T}_{4}$. The text of $\mathrm{T}_{1}{ }^{\mathrm{ac}}$, adopted by all the editions, was obviously corrected based on a manuscript that had an incorrect text corresponding to $\mathrm{M}_{1}$, while the text of $\mathrm{T}_{4}$ might represent a lectio facilior, issuing from the confusion between $g i / h i(t e s s)$ and the suppletion of the syllable bhi at the beginning, replacing the $t i$ of (gitakārthe)ti. Now, whether $\mathrm{T}_{1}$ copied an original manuscript with the reading giteș $\nu$ or whether the scribe restored it-possibly also having $\mathrm{T}_{4}$ in front of him, since some of their readings coincide where $\mathrm{M}_{1}$ has something else — cannot be settled at present. Nevertheless, although showing contamination and editing, $\mathrm{T}_{1}$ is considered a valuable witness in the present edition, midway between a manuscript and an edition.

With regard to group $B$ ), manuscripts $B_{1}, B_{2}, P_{2}, T_{6}$, and $T_{7}$ have not been used in the collation, since they have a lacuna where the relevant passage is given in 
the other set. Some of the manuscripts, however, have been collated for the rest of chapter 4, and their variants, whenever preferred to the editions, have been given in a sort of minimum negative apparatus to the Sanskrit text, supplied in the notes to the various chapters of the book. In particular, $T_{6}$ and $T_{7}$ have been considered, since they are in Malayālam script and since the transcripts in Devanāgarī are clearly copies of these. A number of shared conjunctive errors between $T_{7}, B_{1}$, and $B_{2}$ suggest that $T_{7}$ must reasonably be considered $B_{1}$ and $\mathrm{B}_{2}$ 's common exemplar.

As mentioned above, $B_{1}$ signals lacunae with dots, as for instance in munimunipra ... py eșāpüjāka ... prasañgād (ABh ad Nś 4.1, vol. 1, p. 84). This passage shows the same lacunae and the same repetition 'munimuni' as in $\mathrm{T}_{7}$, which $\mathrm{T}_{6}$ does not display. However, it sometimes differs from $\mathrm{T}_{7}$, suggesting a possible perusal of $\mathrm{M}_{1}$. See, for instance, $\mathrm{ABh}$ ad Nś 4.320, vol. 1, p. 203: gìtakādeś ca] $\Sigma_{\mathrm{E}}$ : gìtādeś ca $\mathrm{A}_{1} \mathrm{D} \mathrm{M}_{1} \mathrm{~T}_{1}{ }^{\mathrm{pc}}$, gìtā $(.$.$) dyasya \mathrm{B}_{2}$, gìtādyo 'sya $\mathrm{T}_{1}{ }^{\text {ac }}$ $\mathrm{T}_{7}{ }^{\mathrm{pc}}$, gìt $\bar{a}\left(\right.$ syo)dyāsya $\mathrm{T}_{6}$, gittādyasya $\mathrm{T}_{7}{ }^{\mathrm{ac}}$. Its exemplar appears to be a Malayālam Ms; cf. ibid. for errors such as tattvāpatty $\left.{ }^{\circ}\right] \mathrm{M}_{1} \mathrm{~T}_{1} \Sigma_{\mathrm{E}}$, tattvā ca ny ${ }^{\circ} \mathrm{B}_{1} \mathrm{~B}_{2} \mathrm{~T}_{7}$, tattvāpaty $^{\circ} \mathrm{A}_{6}$.

$\mathrm{B}_{2}$ starts with a text that is marked as 'Addenda to the volume of Abhinavabhāratī sent by Mr. Govinda D.' These addenda correspond to the text of the GOML manuscript $\left(\mathrm{M}_{1}\right)$, with which the Benares manuscript was subsequently collated, according to what is written in $\mathrm{P}_{2}$, which is a direct copy of $\mathrm{B}_{2}$. Chapters 15 to 17 are also marked as 'supplied', and they do in fact appear to have been supplied from $\mathrm{M}_{1}$. As to $\mathrm{P}_{2}$, the number of chapters and pages make it clear that it cannot be but a copy of $B_{2}$, which itself was copied from a Trivandrum $\mathrm{MS}$ and collated with $\mathrm{M}_{1}$. The first three pages of $\mathrm{P}_{2}$ correspond to the initial four pages supplied in $B_{2}$ from $M_{1}$, and are separated from the following by repeating the title of the work. The part copied thereafter is from the Trivandrum original, whose lacunae had already been filled in $B_{2}$ with the more complete readings of $\mathrm{M}_{1}$. Here, however, the text is copied as a continuum, without signalling the breaks in the text. Only the bracketed parts of $\mathrm{B}_{2}$ are still visible. All of the transcripts in the $\mathrm{B}$ ) group therefore show signs of contamination with $\mathrm{M}_{1}$. As to the exemplar of $\mathrm{B}_{2}$ from Trivandrum, the spaces left in $\mathrm{B}_{2}$ are usually the same as those of $\mathrm{T}_{6}$ and $\mathrm{T}_{7}$; however, the repetition of munimuni $i^{\circ}$, present in $\mathrm{T}_{7}$ but not in $\mathrm{T}_{6}$, suggests that it must be $\mathrm{T}_{7}$, just as in the case of $B_{1}$.

It is now not difficult to determine the identity of the original manuscript, of which T. Ganapati Sastri gave a copy to Ganganath Jha. This same copy was borrowed by Kavi from Govinda Das of Benares (formerly in Viśākhapatnam = Vizagapatnam) and collated with $\mathrm{M}_{1}$. The copy of Govinda Das must later have been given to the Sarasvati Bhavan Library in Benares, where the missing 
parts were again supplied by means of $\mathrm{M}_{1}$. My conclusion is that the Malayālam exemplar of Govinda Das's copy_ which had circulated so widely among early editors- must be $_{7}$, although Kavi indicated its number of chapters as 19 (Kavi 1929:560), which would rather point to $\mathrm{T}_{6}$. It is possible that Kavi was informed about a manuscript with 19 chapters at the Mahārāja's Library in Trivandrum, corresponding to $\mathrm{T}_{6}$, but then received only the copy of $\mathrm{T}_{7}$, also from the Palace Library, which he mistakenly took for $\mathrm{T}_{6}$. He in fact records that 'the late Mr. Gopinath Rao secured in Travancore another copy of the commentary (chs. 1-19) which was as bad as the Palace copy' (ibid.), in all probability corresponding to $\mathrm{T}_{6}$. A direct inspection of $\mathrm{T}_{7}$ shows that this is a much more recent copy, showing similar lacunae to $\mathrm{T}_{6}$, but most probably not a direct copy of $\mathrm{T}_{6}$, since the length of the lacuna sometimes differs and they do not have the same scribal mistakes (for instance the already quoted repetition in $\mathrm{T}_{7}$ munimunipra ...).

Besides the two groups of manuscripts thus isolated, ultimately all copies of $\mathrm{M}_{1}$ or $\mathrm{T}_{6} / \mathrm{T}_{7}$ (except for the exceptional $\mathrm{T}_{1}$ ), a further manuscript merits some attention, namely $\mathrm{T}_{4}$. This is not, properly speaking, a manuscript of the Abhinavabhāratī, but it is a synthesis of its first six chapters (up to the middle of ch. 6), which reproduces most of its text verbatim, but avoids many lengthy passages and sometimes provides a summary. As I have suggested above, it can only be the summary Kavi attributed to Pūrnasarasvatī, although I have not been able to find any evidence in support of its authorship by the renowned Keralite dramatist and literary critic. ${ }^{54} \mathrm{~T}_{4}$ sometimes has better readings, although they have to be considered with some reservations, since the author of this summary might have improved on what was already a corrupt copy of the text. Since $\mathrm{T}^{\mathrm{i}}$ presents the same summarized text, its lineage is safely established. This copy of $\mathrm{T}_{4}$, possibly made by Kavi, has therefore not been considered for collation.

54 Many authors report with scepticism the attribution of such an epitome of the Abhinavabhāratī to Pūrṇasarasvatī on the sole evidence of Kavi's word in the editio princeps. The only connection I can see between $\mathrm{T}_{4}$, which I believe was the epitome seen by Kavi, and Pūrṇasarasvatī is that this author is traditionally associated with the Kāț̣umāțam family (Unithiri 2004:16-17), where the manuscript is said to come from, at least its second part if we follow the colophon. 


\subsection{A Note on the Sanskrit Text and Translation}

In the following section, I present the critical edition of the Sanskrit text of Abhinavagupta's Abhinavabhāratī ad Nātyaśāstra 4.261cd-269ab, furnished with an annotated translation on the opposite pages. The collation work was based on the text of the fourth revised edition of the Gos by Krishnamoorthy from 1992, which was collated with the four manuscripts that contain the relevant passage: $\mathrm{D}, \mathrm{M}_{1}, \mathrm{~T}_{1}$, and $\mathrm{T}_{4}$. Their variants as post correctionem or secunda mano have been also recorded, so that cases of contamination remain visible to the reader. I have also provided the text of $\mathrm{E}_{1(1)}, \mathrm{E}_{1(2)}$, and their variants, as well as $\mathrm{E}_{2}$, whenever different from $\mathrm{E}_{1(4)}$.

In the sections that bear parallels in Hemacandra's Kāryānuśāsana, I have provided the textual variants from the two auto-commentaries Alamkāracud̦ämaṇi (KAA) and Viveka (KAV), as well as the reconstructed passages in Prakrit and Apabhramśa in Bhayani 1993. Though, strictly speaking, these qualify as reference sources, ${ }^{55}$ I have treated them as primary sources for the sake of visibility, and in order to signal places where the editors might have preferred the readings transmitted in the Kāryānuśāsana to those available in the manuscripts. As explained in the previous section, the case of $\mathrm{T}_{4}$ is somewhat comparable to that of the KAA and KAV, since its text represents a case of rewriting by a later author. But while $\mathrm{T}_{4}$ is a summary of the Abhinavabhäratī closer to the original, the commentaries on the Kāryānuśāsana present a more complex case of textual reuse in which the text is rearranged and modified to fit the different context of Hemacandra's discussion of theatrical and dance genres. The Appendix at the end of the book provides the text of Kāryānuśāsana 8.4, with its two commentaries, which feature excerpts from the passage edited here, in the second revised edition of 1964 by Parikh and Kulkarni.

The critical apparatus has three registers: the first, from the top to the bottom, records the textual variations in the manuscripts (in alphabetical order), the editions, and the two commentaries on the Kāryānuśāsana. The middle register indicates longer textual portions where the text in $\mathrm{T}_{4}, \mathrm{KAA}, \mathrm{KAV}$, or elsewhere differs, providing the beginning and end of the passages that vary significantly or are not preserved. These two registers are connected to the transliterated text through line numbers, and occasionally page numbers, whenever the text extends to the following pages. The third layer provides quotations and parallels from the Nâtyaśāstra, indicated in the transliterated text by letters that restart on each new page. This is to avoid confusion with the notes on 
the translation, which proceed in ascending order also on the pages with the Sanskrit text.

As stated repeatedly, the text of the fourth chapter is extremely corrupt, and the manuscript transmission appears to be highly contaminated. Even though errors may not be helpful for understanding the contents of the text, they can be useful in order to individuate genetic relations between manuscripts. The choice of retaining them in the critical apparatus was guided by the consideration that a positive apparatus, however full of scribal mistakes, can certainly be useful as a basis for further comparison of the manuscripts for other portions of the text that may show different characteristics. Moreover, it avoids the unexciting prospect of repeating the process of collation a second time.

As is the standard practice in the publication of Sanskrit texts, the root text, i.e. the Nătyaśāstra, is given in bold characters and followed by the Abhinavabhāratī. Pratīkas and words in the commentary taken from the müla text are also printed in bold. The paragraphs of the translation follow the general layout of the Sanskrit text, which in its turn is largely based on the text of the printed editions. The paragraphs nonetheless have occasionally been divided differently, and punctuation marks have been changed or supplied for the sake of clarity. Changes in punctuation have generally not been indicated in the notes, except when they considerably alter the understanding of the meaning, and the sandhi has been standardized. Loci desperandi, as well as passages in Prakrit and Apabhramśa that I have tentatively restored without any certitude, have been placed within cruces.

An analysis of the text and its contents, with numbers assigned to the different sections and arguments presented, has been prefaced to the edition and translation, with the aim of helping the reader follow the flow of the argumentation and its different interlocutors-in particular, its main divisions into a pürvapakșa and an uttarapakșa, and the two main opponents voicing them: what I have dubbed the abhedapakșin, i.e. the holder of the non-difference between theatre and dance, and the bhedapakșin, i.e. the holder of their difference. The same numbering is maintained in the edition and translation to facilitate their parallel reading. Titles within square brackets have been added in the translation to mark the pürvapakșa and its three main interpretations, as well as the beginning of the uttarapakșa or siddhānta. Words that are not explicit in the Sanskrit text but need to be supplied in the translation for the sake of clarity, additional explicative sentences, and changes of interlocutor have been placed within square brackets.

As a general principle, while translating the Nātyaśāstra-Abhinavabhāratī complex as a textual unit, I have rendered Bharata's text as interpreted in the light of Abhinavagupta's commentary. Within the limits allowed by the terse- 
ness of the müla text, I have opted for a translation of the Nätyaśāstra that is as plain as possible in order to preserve something of its own narrative style and language, which are closer to those of a Purāna. Given the free syntax of some of the verses, however, I was frequently obliged to turn to Abhinavagupta's commentary in order to solve ambiguities or multiple possible interpretations for the same passage. Whenever Abhinavagupta's reading appeared significantly removed from that of Bharata, or from what we can hypothetically reconstruct as attributed to him, I have signalled it in the notes to the translation.

Apart from recording such variation in Abhinavagupta's interpretation of the Nātyaśāstra, the footnotes to the translation also provide a philological rationale whenever I have chosen to translate a reading that is different from the one provided in the text of the edition. My conjectural reconstructions are based, as far as possible, on hypotheses about the textual transmission and corruption, sometimes supported by palaeographic considerations, or by parallel passages in other portions of the Abhinavabhäratī and elsewhere, which are also supplied in the annotations to the translation. On occasion, the critical notes contain a reader-friendly recapitulation of the arguments and how they connect logically with previous or successive steps in the discussion, according to my own numbering in the analysis of the text.

\subsection{Symbols and Abbreviations in the Apparatus}

$\mathrm{ABh}$

Nś

$\mathrm{D}$

$\mathrm{M}_{1}$

$\mathrm{T}_{1}$

$\mathrm{T}_{4}$

$\Sigma_{\mathrm{M}}$

$\mathrm{E}_{1(1)}$

$\mathrm{E}_{1(2)}$

$\mathrm{E}_{1(4)}$

$\mathrm{E}_{1(2)}^{\mathrm{ma}}$

$E_{1(2)}^{\text {bha }}$

$\mathrm{E}_{1}$

$\mathrm{E}_{2}$

$\Sigma_{\mathrm{E}}$
Abhinavabhāratī [pages given according to $\mathrm{E}_{1(4)}$ ]

Nātyaśāstra [pages given according to $\mathrm{E}_{1(4)}$ ]

Abhinavabhäratı̄ manuscript, Delhi National Archives no. 148

Abhinavabhāratī manuscript, GOML Madras no. 2478

Abhinavabhāratı̄ manuscript, ORI Trivandrum no. T $566 \mathrm{~A}$

Abhinavabhäratı̄ manuscript, ORI Trivandrum no. 17703

Reading in all manuscripts

First edition Gos by M. Ramakrishna Kavi

Second edition Gos by K.S. Ramaswami Sastri

Fourth edition Gos by K. Krishnamoorthy

Variants in $\mathrm{E}_{1(2)}$ from Abhinavabhäratī Manuscript no. 14049, Oriental Institute, Baroda

Variants in $\mathrm{E}_{1(2)}$ from Abhinavabhārat̄̄ Manuscript no. 343, BORI, Pune

Reading in GOS $\left(\mathrm{E}_{1(1)}, \mathrm{E}_{1(2)}, \mathrm{E}_{1(4)}\right)$

Edition by Madhusudan Shastri

Reading in all editions 
KAA

KAV

Bhayani

corr.

conj.

nāțya $\rightarrow$ nṛtta

nāttya ... nṛtta

nāțya(...)nṛtta

nātya $\int . . . \int n r t t a$

nāṭya(+1)nṛtta

ac

pc

sm

vl

om.

p.n.p.

$\dagger \ldots \dagger$
Variants in Hemacandra's Alaṃkāracū ḍamaṇi ad Kāvyānuśāsana

Variants in Hemacandra's Viveka ad Kāvyānuśāsana

Variants in Bhayani 1993

correction

conjecture

passage from nātya to nrtta is missing

text breaks off after nātya and continues with nrtta

same, but the lacuna is signalled by an added blank space

illegible syllable(s), occasionally with the number of syllables or the syllables presumed missing given within brackets

missing syllable signalled by the scribe

ante correctionem $=$ before correction

post correctionem $=$ after correction

secunda mano = second hand

varia lectio $=$ variant reading

omitted

passage not preserved

text corrupt beyond reconstruction 